\title{
Glimpses of Oceanic Lithosphere of the Challenger Deep Forearc Segment in the Southernmost Marianas: The $143^{\circ} \mathrm{E}$ Transect, 5800 - $4200 \mathrm{~m}$
}

\author{
Robert J. Stern ${ }^{1}$, Yas Ohara ${ }^{2,3,4}$, Minghua Ren ${ }^{5}$, Matt Leybourne ${ }^{6,7}$, Brent Bowers ${ }^{1}$ \\ ${ }^{1}$ Department of Geosciences, University of Texas at Dallas, Richardson, TX 75083-0688, USA \\ ${ }^{2}$ Hydrographic and Oceanographic Department of Japan, Tokyo 100-8932, Japan \\ ${ }^{3}$ Japan Agency for Marine-Earth Science and Technology, Yokosuka 237-0061, Japan \\ ${ }^{4}$ Department of Earth and Planetary Sciences, Nagoya University, Nagoya 464-8601, Japan \\ ${ }^{5}$ Department of Geoscience, University of Nevada, Las Vegas, NV, USA \\ ${ }^{6}$ Queen's Facility for Isotope Research (QFIR), Department of Geological Sciences and \\ Geological Engineering, Queen's University, Kingston, Ontario, Canada K7L 3N6 \\ ${ }^{7}$ McDonald Institute, Canadian Particle Astrophysics Research Centre, Department of Physics, \\ Engineering Physics \& Astronomy, Queen's University, Kingston, Ontario, Canada K7L \\ $3 N 6$
}

\begin{abstract}
(<500 words)
We studied nine samples of igneous rocks from the inner wall of the Mariana Trench above the Challenger Deep from 4150 to $6100 \mathrm{~m}$ depth recovered by manned submersible and ROV. Samples from two regions that bracket the Moho were studied: A) 7 samples from a N-S transect a few $\mathrm{km}$ to the west of the Shinkai Seep Field; and B) 2 samples from the Shinkai Seep Field. Transect samples include olivine-2 pyroxene hornblendites, amphibole basalts, basaltic andesite, and hornblende andesite. We analyzed three transect samples for ${ }^{40} \mathrm{Ar} /{ }^{39} \mathrm{Ar}$ ages; two yielded good plateau ages of $46.5 \pm 0.5 \mathrm{Ma}$ (hornblendite) and 46.60 $\pm 0.15 \mathrm{Ma}$ (hornblende andesite). These results combined with previously published results, indicate that this crust formed during an intense 46-47 Ma magmatic episode that occurred 5-6 m.y. after subduction initiation. Hornblendites and hornblende basalts formed from primitive magmas, as shown by high $\mathrm{MgO}$ (11 - 21 wt.\%), Ni (222 - 885 ppm) and $\mathrm{Cr}(412$ - 1145 ppm) contents. Electron microprobe analyses indicate that hornblende is Na-rich (up to 3.0 wt. $\% \mathrm{Na}_{2} \mathrm{O}$ ) and that many samples have an atypically large range in plagioclase composition (i.e., individual samples have An < 10 to An 90 plagioclase). Two subgroups can be identified: a mostly deeper depleted suite and a mostly shallower enriched suite. These results indicate that A) the crust-mantle boundary in this region is transitional, occurring over a $\sim 1.5 \mathrm{~km}$ interval, with interlayered peridotite and hornblendites between 5800 and 4300 m; and B) extension to form the Challenger Deep Forearc Segment occurred by combined stretching of old crust and injection of young basaltic magmas. In contrast to the mostly fresh nature of transect samples, the two samples from the Shinaki Seep Field are intensely altered peridotite and basalt.
\end{abstract}

This article has been accepted for publication and undergone full peer review but has not been through the copyediting, typesetting, pagination and proofreading process which may lead to differences between this version and the Version of Record. Please cite this article as doi: $10.1111 /$ iar.12359 


\section{INTRODUCTION}

There is a new urgency to study the oceanic Moho in situ (Witze, 2015). Drilling through oceanic crust is one way to accomplish this, but another way is to find exposed cross sections of the oceanic crust and upper mantle exposed on the seafloor. These can be found at slowspreading ridges, fracture zones, and the inner wall of oceanic trenches. Here we report results from studying a section of oceanic lithosphere exposed on the inner wall of the southernmost Izu-Bonin-Mariana (IBM) trench, in the outer Mariana forearc. This region is very close to the lowest point on Earth's solid surface, so we call this the "Challenger Deep forearc segment".

The IBM convergent margin system stretches $\sim 3000 \mathrm{~km}$ from near Tokyo, Japan to south of Guam, USA (New Fig. 1). The IBM is a textbook example of an intra-oceanic convergent margin and we understand the most important aspects of how it formed $\sim 50 \mathrm{Ma}$ ago and how it has evolved (Stern et al., 2003). This convergent margin is the type locality for modern studies of subduction initiation (SI; Stern and Gerya, 2018). Evidence for how the IBM convergent margin formed is preserved in forearc crust, generated when old Pacific oceanic lithosphere began to founder next to young oceanic lithosphere of what is now the western Philippine Sea plate (Zhou et al., 2018; Arculus et al., 2019).

The IBM trench is exposed in very deep water and is difficult to explore. There are still many aspects of the IBM subduction initiation (SI) story that await resolution, but the SI sequence outlined above is confirmed wherever we examine IBM forearc crust, as far south as south of Guam (Reagan et al., 2019). This corresponds to where the forearc is broad ( $200 \mathrm{~km})$ and stable. Karig and Rankin (1982) noted that "truncation of all forearc elements occurs south of $13^{\circ} 30^{\prime} \mathrm{N}$ '. Forearc geology and evolution is very different west of a sharp discontinuity (the West Santa Rosa Bank Fault, Fig. 2). Karig and Rankin (2003) thought that strike-slip faulting was responsible for the truncation, but we now know that the southernmost Mariana convergent margin is experiencing nearly orthogonal convergence with the Pacific plate at about $3 \mathrm{~cm} /$ year (Bird 2003). We also now know that this region experiences strong extension, as discussed below.

Here we report new mineral chemistry, whole rock major and trace element geochemistry and ${ }^{40} \mathrm{Ar} /{ }^{39} \mathrm{Ar}$ dating of amphibole for samples collected at depth from the inner wall of the outer Mariana forearc, the southernmost trench of the IBM. We use these data to: 1) determine the mineralogy and geochemistry of rocks recovered at the crust-mantle boundary along this part of the IBM; 2) establish the age of the crustal rocks we recovered; and 3) establish the tectonic framework for the southern end of the IBM.

\section{GEOLOGIC BACKGROUND}

The Challenger Deep forearc segment is delimited on the east by the West Santa Rosa Bank Fault (WSRBF), on the south by the Mariana Trench (including the Challenger Deep) and on the north by the Mariana Trough backarc basin (Fig. 2). It is difficult to define the western limit of the Challenger Deep forearc segment at this stage of our understanding; we have explored the eastern parts of the segment much more than the western parts; depending on its western limit, this forearc segment is at least $220 \mathrm{~km}$ across. The WSRBF can be traced as a $>5 \mathrm{~km}$ high scarp south of $13^{\circ} \mathrm{N}$, diminishing in relief northwards (Fig. 2). This latitude is also about where the Mariana Trough spreading axis changes from an axial rift in the north into the inflated Malaguana-Gadao Ridge (MGR; Fig. 2), with the only known magma chamber in the Mariana 
Trough (Becker et al. 2010). Increasing E-W extension southwards in the Mariana backarc is shown by GPS results (Kato et al., 2003), increasing from negligible $\sim 20^{\circ} \mathrm{N}$ to $45 \mathrm{~mm}$ at the latitude of Guam $\sim 13.5^{\circ} \mathrm{N}$. The well-organized Mariana magmatic arc also ends near this latitude, with Tracy Seamount at $13^{\circ} 45^{\prime} \mathrm{N}$ (TS, Fig. 2) being the southernmost arc stratovolcano. The magmatic arc appears to continue SW from Tracey but is represented by multiple small volcanoes of the Alphabet Seamount Province (AS) and Fina Nagu Volcanic Complex (FNVC; Fig. 2). These small volcanoes may reflect strong regional extension, which does not allow the arc magma supply to be concentrated in the same place to allow growth of a stratovolcano. Further evidence for strong extension is provided by the SE Mariana Forearc Rift (SEMFR in Fig. 2), where Ribeiro et al. (2013) showed that MORB-like igneous activity and extension occurred as recently as 3.7 to $2.7 \mathrm{Ma}$. The CDFS forearc is much narrower than the IBM forearc elsewhere and is associated with a poorly developed magmatic arc. The reasons for strong regional extension in the Marianas south of $13^{\circ} \mathrm{N}$ are complex and not fully understood. Gvirtzman and Stern (2003) suggest that the width of the plate-coupling zone is important. Beneath the central Marianas the subducted slab is attached to the upper plate along a 150-kmwide surface that holds the shallow portion of the subducted plate nearly horizontal, in spite of its great load and, thus, counters trench deepening. In contrast, along the south Mariana Trench the subducted length of the lithosphere is much shorter, but it is attached to the upper plate only along a narrower (50-km-wide) surface. In addition, a tear in the slab beneath the WSRBF helps the Pacific/Caroline slab sink rapidly through the mantle, and this combination of circumstances allows the slab to steepen and form the deepest trench on the Earth. A video outlining some of the tectonic complexities of this region can be watched at https://www.youtube.com/watch?time_continue=4\&v=IKGI6t7VM3g\&feature=emb_logo.

The Southern Mariana Forearc Ridge (SMFR; Fig. 2) is marked by series of block uplifts that separate slightly deeper seafloor of the southernmost Mariana Trough to the north from the very deep trench to the south. Uplifted blocks are separated from each other by deeps. This study focuses on the rocks on the southern slope of one of these blocks (Fig. 2).

Another key tectonic element is the West Mariana Ridge (WMR, Fig. 2). This is a textbook example of a remnant arc (Karig, 1972), which separated from the rest of the Mariana arc by rifting to form the Mariana Trough backarc basin. The West Mariana Ridge is poorly sampled but DSDP drilling (Site 451; Fig. 1) recovered volcaniclastic rocks as old as Late Miocene (8-10 Ma); these are overlain by Pliocene and younger pelagic oozes (Party, 1981). The cored sequence suggests that the WMR separated from the active arc by the end of the Miocene, at 5.3 Ma. The eastern edge of the WMR is marked by a steep scarp that can be rotated back against the West Santa Rosa Bank Fault to reconstruct the unrifted Mariana arc.

Recent work on the inner wall of the southernmost Mariana Trench has concentrated around the Shinkai Seep Field (Ohara et al., 2012; Okumura et al., 2016) (white box in Fig. 3). Studies increasingly are biological but the region around it has also been explored. Reagan et al. (2018) studied rocks collected along a crustal profile near $143^{\circ} 03^{\prime} \mathrm{E}$, at similar depths and just east of the present study profile along $142^{\circ} 59^{\prime} \mathrm{E}$.

\section{METHODS}

Cruise YK15-11 aboard R/V Yokosuka involved 2 dives of manned submersible Shinkai 6500 (dives 6K-1431 and 6K-1432) and Cruise KR16-14 aboard R/V Kairei two dives of remotely operated vehicle Kaiko (dives 707 and 708). Because this region is located within the USA Mariana Trench Marine National Monument, the investigations and samplings were done under 
the permission of US Fish and Wildlife Service (\#12541-15002 for YK15-11, and \#12541-16002 for KR16-14). Sample locations are shown on Fig. 3. Samples were studied petrographically and using the electron microprobe at the University of Nevada, Las Vegas. Nine whole rock samples were analyzed for major and trace element concentrations at ALS Geochemistry in Vancouver, Canada (Results in Supp. Table 2). Hornblende crystals were separated from three samples and ${ }^{40} \mathrm{Ar} /{ }^{39} \mathrm{Ar}$ ages were determined for these at the New Mexico Geochronology Laboratory (Results in Supp. Table 3). Detailed procedures are listed in Supplementary Doc. 1.

\section{RESULTS}

\subsection{Sample Petrography and Mineral Chemistry}

We looked $\sim 1700 \mathrm{~m}$ transect of the inner Mariana Trench wall in its middle depths, from $\sim 4150$ to $6100 \mathrm{~m}$ water depth (Fig. 3). We report new results for nine rock samples collected from two Shinkai 6500 manned submersible dives (6K-1431 and 6K-1432) and also two samples collected from two dives of ROV Kaiko (K-707 and K-708) within the Shinkai Seep Field (Ohara et al., 2012; Okumura et al., 2016). The deepest samples were collected at $5600-5700 \mathrm{~m}$ within the Shinkai Seep Field (K-707-R1 and K-708 R7; Fig. 3B). The next deepest are two samples (R4 and R7) from 6K-1431. The shallowest samples are five samples from 6K-1432 (R9, R14, R15, R16, and R17) (Fig. 3A). These are further described below:

K-707-R1: This is a metamorphic rock, containing coarse amphibole, zeolite (natrolite), sodalite, and possibly chlorite (Fig. 4A). The amphibole is mostly actinolite (Fig. 5A). Zeolite veins cut amphibole and sodalite formed along fractures in the veins. The bulk rock is enriched in $\mathrm{Na}_{2} \mathrm{O}$ (13 wt.\%) and has high loss on ignition (LOI: $\left.12 \mathrm{wt} . \%\right)$. This sample was probably originally a mafic rock, maybe a dike or sill, with low abundances of $\mathrm{Cr}$ (5 ppm) and $\mathrm{Ni}(165$ $\mathrm{ppm})$, quite different in this regard from fresh hornblendites 6K1431-R4 and R7. Extreme element mobility is suggested by low abundances of $\mathrm{TiO}_{2}(0.06 \mathrm{wt} . \%)$ and $\mathrm{Zr}(4 \mathrm{ppm})$.

K-708-R7: This is an altered peridotite cut by calcite veins (Fig. 4B, C). The altered nature is revealed by high LOI (26 wt.\%) and high $\mathrm{CaO}(26 \mathrm{wt} . \%)$, which mostly reflect carbonate veins. Its ultramafic protolith is revealed by high $\mathrm{Cr}(578 \mathrm{ppm})$ and $\mathrm{Ni}(1160 \mathrm{ppm})$. Relict minerals are orthopyroxene (opx), spinel, amphibole (Fig. 5A), and minor olivine. Opx is En91Fs8.3-Wo0.7 (Fig. 5D). Spinel has Cr\# 0.45-0.49. Amphibole is magnesio-hornblende to tremolite (Fig. 4c). All other minerals are altered to serpentine group minerals.

6K-1431-R4: This is a pyroxene hornblendite (Fig. 4D). It contains olivine (1\%), opx (15\%), clinopyroxene (cpx) (5\%), spinel (2-3\%), amphibole (78\%), and minor apatite and pyrite. Olivine is anhedral (Fo 80-82; Fig. 5C). Opx and cpx form elongated clusters within amphiboles. Opx is anhedral ( 1 mm), En81-82, Wo0.7 (Fig. 5D). Cpx has a similar shape to opx (Wo47-49, En0.44-0.46; Fig. 5D). Spinel is anhedral and mainly occurs with pyroxene (Cr\# 0.03-0.05; Fig. $5 B)$. Amphiboles are elongated $(1 \times 2-3 \mathrm{~mm})$, the grains are nearly parallel oriented, magnesiohornblende to tschermakite (Fig. 5A). This is a plutonic rock with a fabric; the absence of plagioclase suggests that it formed near the Moho. If so, it was derived from a primitive magma as shown by its content of 19.9 wt.\% MgO, $1110 \mathrm{ppm} \mathrm{Cr}$ and $792 \mathrm{ppm}$ Ni (Supp. Table 2). Compositions of co-existing olivine and spinel plot well to the right of the olivine-spinel mantle array (OSMA; Fig. 5B; Arai, 1994), as expected for cumulates formed by fractional crystallization of mafic magmas. 
6K1431-R7: This is an olivine-2 pyroxene hornblendite with mineralogical layering (Fig. $4 \mathrm{E}$ ). The bands are composed of large ( $\mathrm{mm}$ scale) amphibole and microcrystalline pyroxene $(\sim 100 \mu \mathrm{m})$. Amphibole-rich layers contain large amphibole (tschermakite, Fig. 5A) with rare interstitial cpx. The pyroxene-rich layer contains crystals of ol, opx, cpx, and sp; these tend to be euhderal. Amphibole in the pyroxene-rich bands are compositionally similar to the larger amphiboles. There is serpentinization along some grain boundaries, and is more pronounced in the pyroxene-rich band. Olivine $(<100 \mu \mathrm{m})$ is Fo82, spinel has Cr\# 0.07-0.2. (Fig. 5B). Opx is En82, Cpx is En44-46, Wo46-49 (Fig. 5D). Compositions of co-existing olivine and spinel plot well to the right of the olivine-spinel mantle array (OSMA; Fig. 5B; Arai, 1994), as expected for cumulates formed by fractional crystallization of mafic magmas. This sample is probably a cumulate formed by crystal settling from a water-rich mafic magma. If so, it was derived from a primitive magma as shown by its content of $21.7 \mathrm{wt} \% \mathrm{MgO}, 1145 \mathrm{ppm} \mathrm{Cr}$ and $885 \mathrm{ppm} \mathrm{Ni}$. This magma was derived from a very depleted source, as shown by the sample's content of $0.31 \mathrm{wt}$. \% $\mathrm{TiO}_{2}$ and 0.05 wt. $\% \mathrm{~K}_{2} \mathrm{O}$ (supp. Table 2).

6K-1432-R9: This is a hornblende andesite porphyry (Fig. 4F). It contains euhedral phenocrysts of cpx, amphibole, and plagioclase; amphibole $(1 \mathrm{x} 3 \mathrm{~mm})$ is larger than $\mathrm{cpx}(\sim 1 \mathrm{~mm})$ and plagioclase $(\sim 1 \mathrm{~mm})$. Phenocrysts make up around $25 \%$ of the rock. The matrix is composed of microcrystalline plagioclase $(\sim 100 \mu \mathrm{m})$, rare cpx, amphibole, and glassy material. Cpx is Wo42-46, En41-47 (Fig. 5D). Plagioclase phenocrysts have thin rims around cores of An70-76; rim has similar composition as plagioclase in matrix, An48-54 (Fig. 5C). Groundmass plagioclase is An47-68._Amphibole is magnesio-hornblende (Fig. 5A). Fe-oxide is magnetite with $\sim 4$ wt.\% $\mathrm{TiO}_{2}$. Moderate LOI (2 wt.\%; Supp. Table 2) confirms petrographic evidence that this sample is fresh. This rock contains 62.04 wt.\% $\mathrm{SiO}_{2}, 2.89$ wt.\% $\mathrm{MgO}, 0.43$ wt.\% $\mathrm{TiO}_{2}$, and 1.17 wt. $\% \mathrm{~K}_{2} \mathrm{O}$ (Supp. Table 2). It plots in the "Medium-K calc-alkaline" field in $\mathrm{K}_{2} \mathrm{O}$ vs. $\mathrm{SiO}_{2}$ diagram. This sample gives ${ }^{40} \mathrm{Ar} /{ }^{39} \mathrm{Ar}$ age of $46.60 \pm 0.15 \mathrm{Ma}$ (Fig. 6E, F).

6K-1432-R14: This is a fine-grained basalt, with microphenocrysts of euhedral spinel, anhedral sphene, subhedral plagioclase, anhedral amphibole, and minor apatite and Fe-oxides Fig. 4G). There is some alteration to chlorite, epidote, and zeolite. Grains are tens to hundreds of $\mu \mathrm{m}$. The primitive nature of the magma is reflected in spinel with $\mathrm{Cr} \#$ 0.60-0.67. Surprisingly, plagioclase is An12-16 (Fig. 5C). Subhedral plagioclase is enclosed in anhedral amphiboles. Plagioclase can be altered and contains melt inclusions. Amphibole is magnesio-hornblende to tremolite/actinolite (Fig. 5A). Anhedral amphibole is interstitial to plagioclase. Sphene is anhedral with corroded rims, and contains inclusions. Although LOI is high (3.58 wt.\%; Supp. Table 2), whole rock chemistry indicates that this is a primitive basalt, with $49.5 \mathrm{wt} \% \mathrm{SiO}_{2}, 11$ wt.\% MgO, 450 ppm Cr and 220 ppm Ni (Supp. Table 2). The magma source was very depleted, as shown by whole-rock composition of $0.4 \mathrm{wt} . \% \mathrm{TiO}_{2}$ and $0.15 \mathrm{wt} . \% \mathrm{~K}_{2} \mathrm{O}$. This sample plots in the "Low-K tholeiitic" field in a $\mathrm{K}_{2} \mathrm{O}$ vs. $\mathrm{SiO}_{2}$ diagram and yielded a disturbed ${ }^{40} \mathrm{Ar} /{ }^{39} \mathrm{Ar}$ age (Fig. 6C, D) with no plateau age.

6K-1432-R15: This is a porphyritic basaltic andesite containing 1-2 $\mathrm{mm}$ plagioclase and amphibole phenocrysts. Plagioclase forms large phenocrysts or glomerocrysts (Fig. 4H). Phenocrysts are Ca-rich (bytownite), An83-91 whereas rims and fractures are andesine (An2848). Plagioclase in glomerocrysts are albite to andesine (An5-40). Phenocrysts are altered; plagioclase rims are mainly altered to sericite whereas amphibole is altered to chlorite. The matrix is composed of plagioclase and amphibole micro-phenocrysts. Groundmass plagioclase is An27-30. Amphibole is magnesio-hornblende to actinolite. The rock is moderately altered, with 1.79 wt.\% LOI (Supp. Table 2). This rock is fractionated, with 53.4 wt.\% $\mathrm{SiO}_{2}, 4.1$ wt.\% $\mathrm{MgO}$, 
$30 \mathrm{ppm} \mathrm{Cr}$, and $20 \mathrm{ppm} \mathrm{Ni}$. It contains 0.5 wt. $\% \mathrm{TiO}_{2}$ and 0.85 wt. $\% \mathrm{~K}_{2} \mathrm{O}$ and plots in the "Medium-K calc-alkaline" field in a $\mathrm{K}_{2} \mathrm{O}$ vs. $\mathrm{SiO}_{2}$ diagram.

6K-1432-R16: This is a fine-grained basalt/diabase (Fig. 4I). The rock is composed of about $20 \%$ plagioclase laths randomly distributed with amphibole, and minor sphene, Fe-oxides, pyrite and spinel. There is epidote alteration. Plagioclase are around 100-300 $\mu \mathrm{m}$, with atypically large compositional variation, An5-92. Amphibole, acicular, is magnesio-hornblende to actinolite (Fig. 5A). Irregularly shaped groundmass phases have chemical compositions that are similar to amphibole, with lower $\mathrm{FeO}$ and $\mathrm{MgO}$ contents and higher $\mathrm{Al}_{2} \mathrm{O}_{3}\left(10-28\right.$ wt. \%) and $\mathrm{Na}_{2} \mathrm{O}(1-4$ wt.\%), suggesting that these might be altered amphibole or residual melt. Sphene is irregularly shaped; one grain has $\mathrm{Cr} \# 0.62$. Although moderately altered ( $\mathrm{LOI}=2.88 \mathrm{wt} . \%$ ), this rock is primitive, with 48.7 wt. $\% \mathrm{SiO}_{2} 11$ wt. \% $\mathrm{MgO}, 410 \mathrm{ppm} \mathrm{Cr}$ and $240 \mathrm{ppm} \mathrm{Ni}$. The mantle source was depleted; the sample has 0.4 wt. $\% \mathrm{TiO}_{2}$ and 0.19 wt. $\% \mathrm{~K}_{2} \mathrm{O}$ and plots in the "Low-K tholeiitic" field in a $\mathrm{K}_{2} \mathrm{O}$ vs. $\mathrm{SiO}_{2}$ diagram.

6K-1432-R17: This rock is similar to 6K-1432-R16, but slightly coarser (Fig. 4J), with diabasic texture. Amphibole forms anhedral phenocrysts $(<1 \mathrm{~mm})$. The matrix is dominated by laths of plagioclase (100s of $\mu \mathrm{m})$ and amphibole. Rare small Fe-oxides are found interstitial to plagioclase and amphibole. Plagioclase is An61-85, mainly bytownite (Fig. 5C). Amphibole is magnesio-hornblende to actinolite (Fig. 5A). The rock is moderately altered, as suggested by LOI $=3.04$ wt.\% (Supp. Table 2). It is mafic (48.9 wt.\% $\mathrm{SiO}_{2}$ ) and primitive, with $11 \mathrm{wt} . \%$ $\mathrm{MgO}, 450 \mathrm{ppm} \mathrm{Cr}$, and $270 \mathrm{ppm} \mathrm{Ni}$ (Supp. Table 2). This magma was derived from a depleted source; the sample has $0.4 \mathrm{wt} . \% \mathrm{TiO}_{2}$ and $0.1 \mathrm{wt} . \% \mathrm{~K}_{2} \mathrm{O}$ and plots in the "Low-K tholeiitic" field in a $\mathrm{K}_{2} \mathrm{O}$ vs. $\mathrm{SiO}_{2}$ diagram.

\section{$4.2{ }^{40} \mathrm{Ar} /{ }^{39} \mathrm{Ar}$ ages}

Hornblende separates from three samples (hornblende andesite porphyry 6K-1432- R9, olivine-2 pyroxene hornblendite 6K-1431-R7, and hornblende-bearing basalt 6K-1432-R14) were analyzed for ${ }^{40} \mathrm{Ar} /{ }^{39} \mathrm{Ar}$ ages. The samples were incrementally heated using between 11 and 14 steps (Fig. 6). Hornblendite 6K1431-R07 yields a generally flat age spectrum over the initial $\sim 70 \%$ of gas release with a plateau segment defined by steps $\mathrm{H}-\mathrm{K}$ that have a weighted mean age of $47.2 \pm 0.4 \mathrm{Ma}$ (Fig. 6A). The final 3 steps are somewhat older with step $\mathrm{M}$ being the oldest at about $61 \mathrm{Ma}$. The K/Ca spectrum is very flat and suggests a pure mineral separate. The isochron for steps F-L returns an age of $46.5 \pm 0.5 \mathrm{Ma}$ and the sample has a trapped initial ${ }^{40} \mathrm{Ar} /{ }^{36} \mathrm{Ar}$ value of $319 \pm 6$ (Fig. 6B) which is slightly higher than air. We prefer the 4-step plateau age to the slightly older isochron age because several low ${ }^{39} \mathrm{Ar} /{ }^{40} \mathrm{Ar}$ analyses scatter near the ${ }^{36} \mathrm{Ar} /{ }^{40} \mathrm{Ar}$ intercept. Basalt 6K1432-R14 has a significantly more disturbed age spectrum with the initial steps being as young as $63 \mathrm{Ma}$ before climbing to maximum ages $>300 \mathrm{Ma}$ (Fig. 6C). The K/Ca spectrum is disturbed and shows initially low values for the part of the spectrum that is the flattest and rise markedly for the higher temperature steps. Steps C-F yield an isochron trend with an apparent age of $62.1 \pm 0.7 \mathrm{Ma}$ and a trapped initial ${ }^{40} \mathrm{Ar} /{ }^{36} \mathrm{Ar}$ value of $303.6 \pm 1.6$ (Fig. 6D). Andesite $6 \mathrm{~K} 1432 \mathrm{R} 09$ was well behaved. The initial $\sim 15 \%$ of the spectrum is characterized by ages that decline from $\sim 60 \mathrm{Ma}$ to $\sim 45 \mathrm{Ma}$, followed by a well-defined (MSWD $=0.42$ ) plateau segment that yields a weighted mean age of $46.60 \pm 0.15 \mathrm{Ma}$ (Fig. 6E). The initial disturbed part of the spectrum also displays high K/Ca values that decline to a constant value for the plateau steps. Radiogenic yields are low (20-80\%) for a hornblende of this age; based on the production of ${ }^{39} \mathrm{Ar}$ the sample has a fairly low $\mathrm{K}_{2} \mathrm{O}$-content of 0.15 wt.\% (Supp. Table 3). 


\section{DISCUSSION}

Six topics concerning the geology of the Challenger Deep Forearc segment are explored below: 1) Geochemistry of the samples; 2) Alteration around the Shinkai Seep; 3) Nature of the Crust and the Crust-Mantle transition; 4) Significance of the 46-47 Ma magmatic event; 5) Interesting variations of sodium in plagioclase and hornblendes of the 46-47 Ma igneous rocks; and 6) Where were the young basaltic vents? These are discussed below in this order.

\subsection{Geochemistry}

The nine rocks we studied are mostly mafic igneous rocks, with one each ultramafic and felsic sample. Of particular interest are the samples collected during 6K-1431 and 6K-1432, comprising two Ol-2 pyx hornblendites, four basalts, one basaltic andesite, and one hornblende andesite. Because hornblende is not common in Mariana igneous rocks, the 6K-1431 and 6K1432 suite stands out. The mafic samples in particular are characterized by low $\mathrm{TiO}_{2}(0.31-0.50$ wt. \%) and $\mathrm{K}_{2} \mathrm{O}(0.05-0.15$ wt. \%) and high $\mathrm{MgO}$ (11 - 21 wt.\%), $\mathrm{Ni}(222-885$ ppm), and $\mathrm{Cr}$ contents (412 - $1145 \mathrm{ppm}$ ) (Supp. Table 2). These reflect primitive magmas derived from a depleted mantle source. The 6K-1432 hornblende basalts (R14, R15, R16, R17) are distinctly more primitive and depleted than young basaltic glasses (also listed in Supp. Table 2) (Stern et al., 2014). These compositional similarities suggest that the 6K-1431 Ol 2-pyx hornblendites and $6 \mathrm{~K}-1432$ hornblende basalts were comagmatic and are about the same age. Calculated olivinemelt equilibria for $6 \mathrm{~K} 1431$ olivines and comparison with mafic igneous rock $6 \mathrm{~K} 1431$ real olivine cannot form from melts like 6K1432 basaltic melts; however, they could form in equilibrium with basaltic andesite (6K1432R15). Andesite 6K-1432-R9 and basaltic andesite 6K-1432-R15 share some compositional features with the five very primitive, very depleted mafic samples, including low $\mathrm{TiO}_{2}$ but contain much less $\mathrm{MgO}, \mathrm{Ni}$, and $\mathrm{Cr}$ and significantly more and $\mathrm{K}_{2} \mathrm{O}$; differences in trace elements discussed below support the interpretation that these were derived from a distinctly more enriched mantle source region. The $46.60 \pm 0.15 \mathrm{Ma}$ age for "enriched" hornblende andesite $6 \mathrm{~K}-1432-\mathrm{R} 9$ overlaps with $46.1 \pm 0.7 \mathrm{Ma}$ for diorite and tonalite reported by Reagan et al. (2018); they are within analytical error of each other. These enriched rocks are slightly younger than the $47.2 \pm 0.4 \mathrm{Ma}$ age of depleted ol-2 pyx hornblendite 6K-1431-R7, suggesting rapid temporal evolution of the source from 47 Ma depleted to 46.5 - 46 Ma enriched suites. However, the fact that the andesite was recovered from greater depth than the depleted basalts calls into question any suggestion that the enriched suite is younger than the depleted suite. Further sampling and study will be needed to address this point.

Altered samples K-707-R1 and K-708-R7 have compositions with high LOI (12 - 26 wt.\%). Least mobile major and minor elements such as $\mathrm{Al}_{2} \mathrm{O}_{3}$ and $\mathrm{Cr}$ may preserve the best information about protolith compositions. Low $\mathrm{Al}_{2} \mathrm{O}_{3}$ and high $\mathrm{Cr}$ in K-708-R7 is most consistent with a peridotite protolith; conversely high $\mathrm{Al}_{2} \mathrm{O}_{3}$ and low $\mathrm{Cr}$ in $\mathrm{K}-707-\mathrm{R} 1$ is most consistent with a mafic protolith.

Trace element compositions of the samples we studied along with young basaltic glasses (Stern et al., 2014) and previously reported $46.1 \pm 0.7$ Ma diorite and tonalite (Reagan et al., 2018) are shown in Fig. 7 and Fig. 8; fields for SEMFR basalts to the east are also shown in Fig.

8. These results are broadly consistent with inferences made from major elements above. Olivine-2 pyroxene hornblendites and 6K-1432 basalts (Fig. 7C) are similarly depleted in the light rare earth elements (LREE; Fig. 7A), whereas slightly younger felsic rocks are slightly 
LREE-enriched (Fig. 7C). Primitive 6K-1432 basalts and 6K-1431 hornblendites are also similarly depleted in total REE contents and distinct in this regard from young basaltic glasses (Fig. 7E). In spite of our failure to obtain a robust ${ }^{40} \mathrm{Ar} /{ }^{39} \mathrm{Ar}$ age for the hornblende basalts, we conclude from major and trace element data that $6 \mathrm{~K}-1431$ hornblendites and $6 \mathrm{~K}-1432$ primitive basalts are comagmatic and formed at the same time. Felsic rocks are significantly enriched in trace elements relative to $6 \mathrm{~K}-1431$ hornblendites and $6 \mathrm{~K}-1432$ primitive basalts and these two groups seem magmatically unrelated; basaltic andesite 6K-1432-R15 seems more similar to 6K1432-R9 andesite and 46.1 $\pm 0.7 \mathrm{Ma}$ diorite/tonalite (6K-1236-R14) of Reagan et al. (2018).

Another interesting feature of the 46 - 47 Ma sample suite is that it mostly does not have $\mathrm{La} / \mathrm{Nb}$ expected for subduction-related igneous rocks. Condie (2003) showed that $\mathrm{La} / \mathrm{Nb}=1.4$ effectively discriminated convergent margin mafic suites (with higher $\mathrm{La} / \mathrm{Nb}$ ) from MORB and OIB (with lower $\mathrm{Nb} / \mathrm{La}$ ). 6K-1431 hornblendites have $\mathrm{La} / \mathrm{Nb} \sim 0.5,6 \mathrm{~K}-1432$ primitive basalts have $\mathrm{La} / \mathrm{Nb}=1.1,1.5$, and 0.94 and basaltic andesite has $\mathrm{La} / \mathrm{Nb}=0.76$. Only the andesite $(\mathrm{La} / \mathrm{Nb}=2.0)$ and tonalite/diorite $(\mathrm{La} / \mathrm{Nb}=2.5-3.6)$ have the high $\mathrm{La} / \mathrm{Nb}$ expected for arc lavas.

Figure 8A shows that the trace element composition of igneous rocks studied here are mostly MORB-like and that 6K-1431 and 6K-1432 samples are similar in this regard to young basaltic volcaniclastic rocks (Stern et al., 2014) and SEMF basalts (Ribeiro et al., 2013). Figure 8B shows that these samples show little subduction zone enrichment except for $6 \mathrm{~K}-1432$ andesite and diorite/tonalite studied by Reagan et al. (2018).

It is unclear to what extent the altered rocks collected around the Shinkai Seep Field retain their original composition and to what extent this has been modified by alteration. Altered peridotite 708-07 has very low REE contents ( $<<1 \mathrm{x}$ chondritic) and a U-shaped pattern (Fig. 7A). However, its extended trace element pattern shows tremendous enrichments in $\mathrm{U}$ and $\mathrm{Sr}$ and substantial enrichment in $\mathrm{Ba}$ (Fig. 7B). These spikes are not seen in other peridotites recovered from the region and are surely due to alteration associated with the Shinkai Seep Field.

\subsection{Alteration around the Shinkai Seep Field}

Pervasive alteration of rocks around the Shinkai Seep Field is expected because there is a history of fluid flow in this area. Altered peridotites like K-708-R7 are expected here but finding an altered mafic rock like K-707-R1 with sodalite, natrolite, and actinolite, is a surprise. Little more can be said based on only two samples. More work is needed to delimit the region affected and assess the significance of altered rocks around the Shinkai Seep Field.

\subsection{Nature of the Crust and the Crust-Mantle Transition}

Samples from the four dives studied here (6K-1431, 6K-1432, Kaiko-707, Kaiko-708) encompass a transect 6100 to $4150 \mathrm{~m}$ deep through the upper part of the inner trench wall (Fig. 9). This transect encompasses $\sim 1500 \mathrm{~m}$ vertical relief bracketing the Moho northeast of the Challenger Deep. These results indicate that the crust-mantle boundary is transitional, with the deepest non-peridotites being the K-707-R01 altered rock collected at $5700 \mathrm{~m}$ and the 6K-1431 hornblendites collected at $5150 \mathrm{~m}$ (Fig. 7). Peridotites dominate below these depths, including the very altered peridotites recovered at $5700 \mathrm{~m}$ south of the Shinkai Seep Field. Metamorphic rocks collected deeper, including hornblende garnetite $(6 \mathrm{~K}-1232-\mathrm{R} 07 ; 6276 \mathrm{~m})$ and two epidote amphibolites (6K-1232-R13, $6046 \mathrm{~m}$ and 6K-1232-R16, $5934 \mathrm{~m})$ reported by Reagan et al. 
(2018) are important exceptions. The hornblende garnetite yielded Lu-Hf and Sm-Nd mineral isochron ages of $25.21 \pm 0.47$ and $24.8 \pm 2.5 \mathrm{Ma}$ and hornblende ${ }^{40} \mathrm{Ar} /{ }^{39} \mathrm{Ar}$ ages of $25.20 \pm 0.86$ Ma (Reagan et al., 2018), indicating that it formed 21 m.y. after the 46-47 Ma crust-forming event. Pressures of $1.2 \mathrm{GPa}$ or higher $\left(\sim 40 \mathrm{~km}\right.$ deep) and $\mathrm{T}>850^{\circ} \mathrm{C}$ are calculated for the hornblende garnetite, suggesting metamorphism in a hot subduction zone. This evidence of a significantly younger metamorphic event suggests that structural complexities may be expected at greater depths. It is possible that the altered mafic rock (K-707-R1) collected in the Shinkai Seep Field is related to these metamorphic rocks; further work is needed to address this possibility. Peridotites were recovered as shallow as $4500 \mathrm{~m}$ during $6 \mathrm{~K}-1432$, indicating that the Moho along this transect is significantly shallower than the $\sim 5600 \mathrm{~m}$ deep Moho documented $\sim 5$ $\mathrm{km}$ to the east, north of the Shinkai Seep Field. This difference in Moho depth estimated from two transects that are so close to each other indicates that care must be taken to map the Moho farther west and east of this region.

Sampling of the forearc $\sim 50 \mathrm{~km}$ to the east was reported by Ohara and Ishii (1998). KH92-1-D2 (143 $\left.29.6^{\prime} \mathrm{E}, 7431-6594 \mathrm{~m}\right)$ recovered $280 \mathrm{~kg}$ of peridotite, pyroxenite, and metamorphic rocks. A few km to the NW, Shinkai Dive 157 (143ํ26.5'E, 6083-5789 m) recovered five samples of peridotite. Some peridotites contained significant proportions of hornblende, suggesting a possible link to $6 \mathrm{~K}-1431$ olivine- 2 pyroxene hornblendites; these could be related to the 46-47 Ma amphibole-rich suite studied here

An interesting feature of the crustal section studied along the $143^{\circ} \mathrm{E}$ transect is that gabbro was not found. The only plutonic rocks encountered are the 6K-1431 olivine 2-pyx hornblendites sampled between 5400 and $4600 \mathrm{~m}$ depth and the hornblende quartz diorite/ tonalite (6K-1236-R14) reported by Reagan et al. (2018). Gabbros are common if not abundant components of the Mariana forearc dredged between $16^{\circ}$ and $18^{\circ} \mathrm{N}$ (Bloomer 1983). Mylonitic troctolite and gabbro was recovered by dredge from $8100-8400 \mathrm{~m}$ water depths in D1403 SE of Guam (Dietrich et al. 1978) but gabbro was not abundant here either.

Another surprise are the hornblende-rich mafic rocks recovered during 6K-1431. These have some boninitic tendencies in terms of their high $\mathrm{MgO}(20 \mathrm{wt} . \%), \mathrm{Cr}(1100 \mathrm{ppm})$ and $\mathrm{Ni}$ (800 ppm) concentrations and low $\mathrm{TiO}_{2}(0.3$ wt. $\%), \mathrm{Al}_{2} \mathrm{O}_{3}(10-11$ wt. $\%$ ) abundances, presence of abundant opx and lack of plagioclase, but not in terms of their $\mathrm{SiO}_{2}$ concentrations (45 wt.\%) and presence of amphibole.

The section we sampled from 4150 to $6100 \mathrm{~m}$ depth is dominated by ultramafic rock and there is a notable lack of the gabbro that forms the lower crust. This implies that the entire 1,950 $\mathrm{m}$ thick section brackets the crust-mantle transition. Comparing our results with seismic measurements of the crust-mantle transition in oceanic crust globally (Prodehl and Mooney, 2012) confirms that the crust-mantle transition beneath ocean basins and arc crust displays significant variation in thickness, reaching an extreme value of $5000 \mathrm{~m}$ at the SW Greenland margin. In such cases the Moho will be diffuse in near-vertical incident seismic reflection data, However, the transitional structure of the Moho will be revealed by seismic refraction and wideangle reflection data.

\subsection{Significance of the 46-47 Ma Magmatic Event in the Challenger Deep Forearc Segment}

Igneous rocks collected during 6K-1432 are volcanic. The sample suite includes three primitive basalts, one basaltic andesite and one andesite. All five samples contain abundant hornblende, 
indicating that these were hydrous magmas. The two crustal samples collected during $6 \mathrm{~K}-1431$ are plutonic hornblendites. These two suites are similar in terms of abundance of amphibole, elevated $\mathrm{Mg}, \mathrm{Cr}$, and $\mathrm{Ni}$, low $\mathrm{Ti}, \mathrm{K}$, and $\mathrm{Ba}$, and inferred similar age as discussed in the next section. An unusual feature of $6 \mathrm{~K}-1432$ mafic rocks is the large range of plagioclase compositions observed, both in individual samples and in the suite as a whole. Primitive basalt 6K-1432-R14 plagioclase is An12-16, basaltic andesite 6K-1432-R15 has An5-91, primitive basalt 6K-1432-R16 has An5-92, and primitive basalt 6K-1432-R17 has An61-85. Such a wide range of plagioclase compositions in primitive mafic igneous rocks is unheard of and very difficult to explain.

The crustal suite (6K-1431 and 1432) studied here appears to have formed in a single magmatic episode at 46-47 Ma, as evidenced by common occurrence of magmatic amphibole, primitive nature of mafic samples, and two similar ages, 47.2 $\pm 0.4 \mathrm{Ma}$ for hornblendite $6 \mathrm{~K}$ 1431-R7 and 46.6 $\pm 0.15 \mathrm{Ma}$ for andesite $6 \mathrm{~K}-1432-\mathrm{R} 9$. These ages are very similar to a U-Pb zircon age for a mixed hornblende-bearing quartz diorite/tonalite (6J-1236-R14) collected a few $\mathrm{km}$ to the east, at $5899 \mathrm{~m}$ north of Shinkai Seep Field, for which Reagan et al. (2018) reported a $\mathrm{U}-\mathrm{Pb}$ zircon age of $46.1 \pm 0.7 \mathrm{Ma}$ (Fig. 3). These results, considered together, indicate that a 46 47 Ma magmatic episode characterized by abundant hornblende was important in the geologic evolution of the region. These rocks are the first documented evidence for the older crust that was stretched to form the Southern Mariana Forearc Ridge (Fig. 2). More work is needed to determine if similar rocks make up the crust of other SMFR blocks to the east and west. Regardless, the 46 - 47 Ma crust is a bit younger than the initial outpourings associated with subduction initiation to form the IBM convergent margin. Slightly older MORB-like basalts and gabbros with radiometric ages of 48 - $52 \mathrm{Ma}$ form the oldest crust exposed in the IBM forearc to the east of $144^{\circ} \mathrm{E}$ and farther north (Fig. 10; Reagan et al., 2010; Ishizuka et al., 2018). These forearc basalts (FAB) are overlain by 44 - $48 \mathrm{Ma}$ boninites and 43 - $45 \mathrm{Ma}$ high-Mg andesites. This sequence is taken to indicate that it takes $\sim 8 \mathrm{~m}$.y. to establish a mature subduction zone (Ishizuka et al., 2018). In this sequence, it seems that the 46 - 47 Ma rocks we studied fit into the boninite episode (Fig. 10). As noted previously, the rocks we studied are not boninites but may be related because of their high $\mathrm{MgO}, \mathrm{Cr}$, and $\mathrm{Ni}$ contents. The ubiquitous presence of hornblende also ties them to a subduction-related setting. More work is needed to understand what, if any, relationship the 46 - 47 Ma SMFR crustal suite has to IBM boninites.

It is unclear how widespread the 46 - 47Ma igneous event in the southern Marianas was, but it may have been significant. The oldest rocks of Saipan, the Sankakuyama rhyodacite, may have formed during this episode. Sample SPN02-13 yielded the best ${ }^{40} \mathrm{Ar} /{ }^{39} \mathrm{Ar}$ age of two samples reported by Reagan at al. (2008), $45.1 \pm 0.3 \mathrm{Ma}$. This is very close to the age of the 46 47 Ma magmatic episode documented for the Challenger Deep forearc segment. We only have K-Ar ages for Guam's oldest rocks, where Meijer et al. (1983) reported a K-Ar age of $43.8 \pm 1.6$ Ma for a Facpi Formation basaltic andesite; we suspect that application of more ${ }^{40} \mathrm{Ar} /{ }^{39} \mathrm{Ar}$ will result in a slightly older ( 2-4 m.y.) age.

\subsection{Interesting variations of Sodium in Plagioclase and Hornblendes of the 46-47 Ma Igneous rocks}

Both amphibole and plagioclase show large variations in $\mathrm{Na}_{2} \mathrm{O}$ contents, with amphibole up to 3.5 wt.\% $\mathrm{Na} 2 \mathrm{O}$ and plagioclase as sodic as around An5 (near 12 wt.\% $\mathrm{Na}_{2} \mathrm{O}$ ) (Fig. 11).

Basaltic andesite 6K1432R15 has the largest range in anorthite contents; the most albitic portions 
(An5) occur along phenocryst and glomerocryst rims. We interpret the albite-rich rims to reflect non-pervasive hydrothermal alteration; although in the core of a hydrothermal reaction zone plagioclase can be essentially reset to albite (Leybourne and Goodfellow, 1994), less pervasive alteration is also common (Miron et al., 2012). Alteration in this sample is consistent with abundant pyrite in the matrix (and relatively high whole rock $\mathrm{Fe}_{2} \mathrm{O}_{3}$ as a result). The most sodic plagioclase in sample 6K1432R15 has low FeO contents, consistent with coeval pyrite and albite alteration, partitioning Fe into the sulfide phase. The most sodic amphibole phenocrysts occur in Ol 2 pyx hornblendites with little or no plagioclase; lack of plagioclase results in Na partitioning essentially completely into amphibole. These Na-rich amphiboles also have lower $\mathrm{FeO}$ and $\mathrm{MnO}$ (latter shown in Fig. 11A) and slightly higher $\mathrm{MgO}$ contents, consistent with magmatic fractionation. Basaltic andesite 6K1432R15 with the most sodic plagioclase rims is also characterized by low $\mathrm{Na}_{2} \mathrm{O}$ contents in amphibole in the matrix, suggesting that the sodic plagioclase is an alteration feature, with partitioning of $\mathrm{Na}_{2} \mathrm{O}$ into newly formed albite. Although partitioning of $\mathrm{Na}$ between amphibole and plagioclase can favor the former (Molina et al., 2015), during metamorphism/metasomatism, with increasing temperature plagioclase becomes more calcic and amphibole more sodic (Spear, 1981)

\subsection{Whither the Vents for Young Basaltic Volcaniclastics?}

The Challenger Deep Forearc Segment has been affected by basaltic igneous activity. This is best known from the SE Mariana Forearc Rift (Fig. 2), which is a NNW-SSE trending rift zone at least $20 \mathrm{~km}$ across, floored by 3.7 -2.7 Ma ( ${ }^{40} \mathrm{Ar} /{ }^{39}$ Ar ages) MORB-like tholeiitic basalts (Ribeiro et al., 2013). SEMFR basalts testify to recent decompression melting of asthenosphere, which requires strong extension of the Challenger Deep forearc segment. Stern et al. (2014) reported evidence of young basaltic volcanism from the present study area ca. $100 \mathrm{~km}$ west of SEMFR ("BB" in Fig. 3A). Shinkai 6500 diving during 6K-1363 (Figs. 3 and 9) recovered volcaniclastic rocks from 5.5 to $6 \mathrm{~km}$ deep in the inner wall of the Mariana Trench. These contain irregular fragments of MORB-like basaltic glass set in a palagonite-rich matrix. These volcaniclastic rocks are poorly sorted, well indurated, and show no lamination or bedding. Stern et al. (2014) interpreted the volcaniclastic rocks as bottom-hugging gravity flows that moved downslope as a result of oversteepening around an eruption site on the inner trench slope. Harzburgite fragments suggest the eruption site was below $\sim 4.5 \mathrm{~km}$ water depth. This is consistent with two young volcaniclastic samples collected $\sim 4.5 \mathrm{~km}$ depth. We still have not found the eruption site but it seems it was $\sim 4.5 \mathrm{~km}$ deep and perhaps a few hundred meters to the west of our transect.

\section{CONCLUSIONS}

We conducted a geologic transect from 6150 to $4100 \mathrm{~m}$ depth up the inner trench wall of the Challenger Deep Forearc Segment in the southernmost Mariana convergent margin within and a few kilometers west of the Shinkai Seep Field. We report detailed results for 7 samples collected along a $2 \mathrm{~km}$ transect across the crust mantle transition and two very altered samples collected in the Shinkai Seep Field. We discovered that the crust is characterized by distinctive hornblenderich plutonic and volcanic rocks that formed 46-47 Ma. This is the first documented evidence for older crust that was stretched to form the Southern Mariana Forearc Ridge. The results also 
indicate that the crust-mantle boundary here is transitional of an interval that is a least $1.5 \mathrm{~km}$ thick, with interlayered peridotite and hornblendites between 5800 and $4300 \mathrm{~m}$.

As a result of several cruises to explore the geology of the upper half of the inner slope of the Challenger Deep Forearc Segment, we have an inkling of what it is composed of and how it formed. From regional considerations we know that this region was created by strong extension over the past few millions of years as the Mariana Trough backarc basin widened; at least 220 $\mathrm{km}$ of extension has occurred over this time. We now know that this forearc ridge is underlain by both older (largely Eocene) and much younger crust, formed by Pliocene and younger MORBlike basaltic volcanism. From these considerations, we conclude that extension to produce the Southern Mariana Forearc Ridge was accomplished by a combination of mechanical extension of older crust (like the 46-47 Ma crust documented in this study) and much younger basaltic magmatism like that of the SE Mariana Forearc Rift. We do not yet know what proportion of the forearc is composed of younger vs. older crust; future research will determine this. However, there are significant variations in bathymetry along the ridge summit, breaking it into a series of highs and lows (Fig. 2), and these give clues as to the nature of associated crust. Isostasy predicts that highs are underlain by thicker crust and lows underlain by thinner crust. High-standing blocks like that studied here are likely to be dominated by thicker (=older?) crust whereas lowstanding regions like SEMFR are more likely to be dominated by thinner (=younger?) basaltic crust. The N-S lines a-j in Fig. 2 show where future research might be usefully conducted. The results of transect "a" are reported here; we predict that transects b-f up slopes of similar highstanding blocks will mostly find older crust. In contrast, transects g-j up the slopes of lowstanding regions are predicted to encounter young basalts. Detailed magnetic and gravity surveys across this region would also help map regions of thicker, older and thinner, younger crusts.

A likely benefit of further exploring by conducting these transects will be the discovery of other vents like the Shinkai Seep Field. Cool forearc seeps this have far lower energy and mass fluxes than high temperature smokers and can only be discovered by bottom observations, which is how the Shinkai Seep Field was discovered (Ohara et al., 2012). Some forearc vents sit on top of large submarine mud volcanoes (e.g., Wheat et al., 2020), but the Shinkai Seep Field has no bathymetric expression and other similar vents in the tectonically active Challenger Deep Forearc Segment are also unlikely to have significant bathymetric expression. It may be that zones of intense alteration around these seeps may change the magnetic field over them and that near-bottom magnetic surveys might help find these, but that possibility is not yet demonstrated. Until this and other geophysical methods can be developed for finding these vents, we will have to explore this region with manned submersible, ROV, and AUVs to find more.

\section{ACKNOWLEDGEMENTS}

The authors thank the crew of the R/V Yokosuka and R/V Kairei for their professional support during the YK15-11 and KR16-14 cruises. This study was conducted under a special permit of the US Fish and Wildlife Service for studies in the Mariana Trench Marine National Monument. We thank Matt Heizler and the New Mexico Geochronology Research Laboratory for ${ }^{40} \mathrm{Ar} /{ }^{39} \mathrm{Ar}$ ages. We also thank Mark Reagan for timely insights about ages and Walter Mooney for deep thoughts about the Moho. We also appreciate thoughtful reviews by Yoshi Tamura and an anonymous referee. This is UTD Geosciences contribution \# 1368. 


\section{References}

Arai, S., 1994. Characterization of spinel peridotites by olivine-spinel compositional relationships: Review and interpretation. Chemical Geology 113, 191-204.

Arculus, R.J., Gurnis, M., Ishizuka, O., Reagan, M.K., Pearce, J. A., and Sutherland, R. 2019. How to Create New Subduction Zones. Oceanography 32, 160-174.

Becker N. C., Fryer P. and Moore G. F. 2010. Malaguana-Gadao Ridge: Identification and implications of a magma chamber reflector in the southern Mariana Trough. Geochemistry Geophysics Geosystems 11, Q04X13.

Bloomer, S.H. 1998. Distribution and Origin of Igneous Rocks From the Slopes of the Mariana Trench: Implications for Its Structure and Evolution. J. Geophys. Research 88(B9),74117428

Condie, K.C., 2003. Incompatible element ratios in oceanic basalts and komatiites: Tracking deep mantle sources and continental growth rates with time. Geochemistry, Geophysics, Geosystems 4(1) http://dx.doi.org/10.1029/2002GC000333

Dietrich, V., Emmerman, R., Oberhansli, R., and Puchelt, H, 1978. Geochemistry of Basaltic and Gabbroic Rocks from the West Mariana Basin and the Mariana Trench. Earth and Planet. Sci. Lett. 39, 127-144.

Gvirtzman, Z., and Stern, R.J., 2004. Bathymetry of Mariana Trench-Arc System and Formation of the Challenger Deep as a Consequience of Weak Plate Coupling. Tectonics, TC2011, doi:10.1029/2003TC001581,

Izhizuka, O., Hickey-Vargas, R., Arculus, R.J., Yogodzinski, G.M., Savov, I.P., Kusano, Y., McCarthy, A., Brandt, P.A., and Sudoo, M., 2018. Age of Izu-Bonin-Mariana basement. Earth Planet. Sci. Lett. 481, 80-90.

Karig, D.E., 1972. Remnant Arcs. GSA Bull. 83, 1057-1068.

Karig, D.E., and Rankin, B., 1983. Marine Geology of the Forearc, Southern Mariana Island Arc. In The Tectonic and geologic evolution of the Southeast Asian Seas and Island. AGU Monograph 27, p. 266-280.

Kato, T., J. Beavan, T. Matsushima, Y. Kotake, J. Camacho, T. Jaun, and S. Nakao, 2003. Geodetic evidence of backarc spreading in the Mariana Trough, Geophys. Res. Lett., 30, 1625, doi:10.1029/2002GL016757. 
Larocque, J. and Canil, D. (2009) The role of amphibole in the evolution of arc magmas and crust: the case from the Jurassic Bonanza arc section, Vancouver Island, Canada. Contributions to Mineralogy and Petrology 159, 475-492

Leybourne, M.I. and Goodfellow, W.D. 1994. Mineralogy and mineral chemistry of hydrothermally altered sediment, Middle Valley, Juan de Fuca Ridge, Proceedings of the Ocean Drilling Program, Scientific Results. Ocean Drilling Program, College Station, Texas, pp. 155-206.

Meijer, A., Reaggan, M., Ellis, H., Shafiiqullah, M., Sutter, J., Damon, P., and Klingg, S., 1983. Chronology of Volcanic Events in the Eastern Philippine Sea. In The Tectonic and geologic evolution of the Southeast Asian Seas and Island. AGU Monograph 27, p. 349-359.

Meschede, M. (1986) A method of discriminating between different types of mid-ocean ridge basalts and continental tholeiites with the Nb-Zr-Y diagram. Chemical Geology 56, $207-$ 218.

Michibayashi, K., Ohara,Y., Stern, R.J., Fryer, P., Kimura, J.-I., Tasaka, M., Harigane, Y., and Ishii,, T., 2009. Peridotites from a ductile shear zone within back-arc lithospheric mantle, southern Mariana Trench: Results of a Shinkai 6500 Dive. Geochemistry, Geophysics, Geosystems 10(5) https://doi.org/10.1029/2008GC002197

Miron, G.D., Neuhoff, P.S. and Amthauer, G. (2012) Low-Temperature Hydrothermal Metamorphic Mineralization of Island-Arc Volcanics, South Apuseni Mountains, Romania. Clays and Clay Minerals 60, 1-17.

Molina, J.F., Moreno, J.A., Castro, A., Rodríguez, C. and Fershtater, G.B. (2015) Calcic amphibole thermobarometry in metamorphic and igneous rocks: New calibrations based on plagioclase/amphibole Al-Si partitioning and amphibole/liquid Mg partitioning. Lithos 232, 286-305.

Ohara, Y., and Ishii, T., 1998. Peridotites from the southern Mariana forearc: Heterogeneous fluid supply in mantle wedge. Island Arc 7, 541-558.

Ohara, Y., Reagan, M.K., Fujikura, K., Watanabe, H., Michibayashi, K., Ishii, T., Stern, R.J., Pujana, I. Martinez, F., Giraud, G., Ribeiro, J., Brounce, M., Komori, N., Kino, M. 2012. A serpentinite-hosted ecosystem in the Southern Mariana Forearc. Proceedings of the National Academy of Science of the United States of America, 109, 2831-2835, www.pnas.org/cgi/doi/10.1073/pnas.1112005109

Okumura, T., Y. Ohara, R.J. Stern, T. Yamanaka, Y. Onishi, H. Watanabe, C. Chen, S.H. Bloomer, I. Pujana, S. Sakai, T. Ishii, and K. Takai, Brucite chimney formation and carbonate alteration at the Shinkai Seep Field, a serpentinite-hosted vent system in the southern Mariana forearc. 2016. Geochemistry, Geophysics, Geosystems, 17, 3775-3796, DOI:10.1002/2016GC006449. 
Pearce, J.A. (2008) Geochemical fingerprinting of oceanic basalts with applications to ophiolite classification and the search for Archean oceanic crust. Lithos 100, 14-48.

Prodehl, C and W.D. Mooney, 2012, Exploring the Earth's crust; history and results of controlledsource seismology, Geological Soc. Am Memoir 208, 764 pp.

Reagan, M. K., Hanan, B. B., Heizleer, M. T., Hartman, B. S. and Hickey-Vargas, R., 2008. Peetrogenesis of Volcanic Rocks from Saipan and Rota, Mariana Islands, and Implications for the Evolution of Nascent Island Arcs. J. Petrology 49, 441-464

Reagan, M.K., O. Ishizuka, R.J. Stern, K.A. Kelley, Y. Ohara, J. Blichert-Toft, S.H. Bloomer, J. Cash, P. Fryer, B.B. Hanan, R. Hickey-Vargas, T. Ishii, J.-I. Kimura, D.W. Peate, M.C. Rowe, and M. Woods, 2010. Fore-arc basalts and subduction initiation in the Izu-BoninMariana system, Geochemistry, Geophysics, Geosystems, 11, Q03X12, doi:10.1029/2009GC002871.

Reagan, M.K., Heywood, L., Goff, K., Michibayashi, K., Foster, C.T., Jr., Jicha, B., Lapen, T., McClelland, W.C., Ohara, Y., Righter, M., Scott, S., and Sims, K.W.W., 2018, Geodynamic implications of crustal lithologies from the southeast Mariana forearc: Geosphere, v. 14, no. 1, p. 1-22, doi:10.1130/GES01536.1.

Reagan, M., Heaton, D.E., Schmitz, M.D., Pearce, J.A., Shervais, J.W., and Koppers, A.A.P., 2019. Forearc ages reveal extensive short-lived and rapid seafloor spreading following subduction initiation. Earth and Planet. Sc. Lett. 506, 520-529.

Ribeiro, J.M., Stern, R.J., Martinez, F., Ishizuka, O., Merle, S.G., Kelley, K., Anthony, E. Y., Ren, M., Ohara, Y., Reagan, M., Girard, G., and Bloomer, S.H., 2013. Geodynamic evolution of a forearc rift in the southernmost Mariana Arc. The Island Arc 22, 453-476

Ribeiro, J.M., Stern, R.J., Kelley, K.A., Martinez, F., Ishizuka, O., Manton, W.I. and Ohara, Y. (2013) Nature and distribution of slab-derived fluids and mantle sources beneath the Southeast Mariana forearc rift. Geochemistry, Geophysics, Geosystems 14, 4585-4607.

Shipboard Scientific Party. 1981. Site 451: East Edge of the West Mariana Ridge. Deep Sea Drilling Project Initial Reports 59, 405-483.

Spear, F.S. (1981) Amphibole-plagioclase equilibria: An empirical model for the relation albite+tremolite=edenite+4 quartz. Contributions to Mineralogy and Petrology 77, 355-364.

Stern, R.J., Fouch, M.J., and Klemperer, S., 2003. An Overview of the Izu-Bonin-Mariana Subduction Factory in J. Eiler and M. Hirschmann (eds.) Inside the Subduction Factory, Geophysical Monograph 138, American Geophysical Union, 175-222.

Stern, R.J., Ren, M., Kelley, K.A., Ohara, Y., Martinez, F., Bloomer, S.H.' 2014. Basaltic volcaniclastics from the Challenger Deep forearc segment, Mariana convergent margin: Implications for tectonics and magmatism of the southernmost Izu-Bonin-Mariana arc. The 
Island Arc 23, 368-382.

Stern, R. J., Tamura, Y., Masuda, H. et al. 2013. How does the Mariana Arc end in the south? The Island Arc 22, 133-148

Whear, C.G., Seewald, J. S., and Takai, K., 2020. Fluid transport and reaction processes within a serpentinite mud volcano: South Chamorro Seamount. Geochim. Cosmochim. Acta 269, 413-428.

Witze, A., 2015. Quest to drill into Earth's mantle restarts. Nature 528, 16-17

Zhou, X., Li, Z.-H., Gerya, T.V., Stern, R.J., Xu, Z., and Zhang, J., 2018. Subduction initiation dynamics along a transform fault control trench curvature and ophiolite ages. Geology 46, 607-610.

\section{FIGURE CAPTIONS}

Fig. 1: Locality map showing the location of the Izu-Bonin-Mariana Arc in the Western Pacific. Location of DSDP site 451 and Fig. 2 also shown.

Fig. 2: Bathymetric map of the southernmost Mariana convergent margin, showing location of the study area (Fig. 3a). The black line show the location of $\mathrm{N}-\mathrm{S}$ profile along $143^{\circ} \mathrm{E}$ (Fig. 6). The stars show the location of dredge site KH92-1-D2, where most of the analyzed samples in Ohara and Ishii (1998) come from.

Fig. 3: Detail of study area showing location of Shinkai dives 6K-1431 and 1432 (A) and Kaiko dives 707 and 708 (B) studied here. Solid narrow lines reflect dive tracks reported in this study, dashed dive tracks are from previous studies, also 6K-1364 which recovered only peridotite. Also shown are where metamorphic garnetite and amphibolite from 6K-1232 and diorite/tonalite from 6K-1236 were reported by Reagan et al. (2018). Also shown are where three samples of volcanic breccia recovered by Shinkai 6500 dive 6K-1363 were reported by Stern et al. (2014). A) Location of studied samples (given in parentheses) are shown. B) location of studied samples from the Shinkai Seep Field shown with white star. Red dot indicates brucite/carbonate chimney site, whereas yellow circle calyptogena colony site. Figure modified after Okumura et al. (2016).

Fig. 4: Photomicrographs (crossed polars) and hand specimen photos of studied samples. A) Photomicrograph of K-707-R1 metamorphosed mafic rock, containing coarse amphibole, zeolite (natrolite), sodalite, and possibly chlorite. B) Cut hand specimen of altered peridotite $\underline{\text { K-708-R7 }}$ altered peridotite showing relationships between dark green peridotite and white calcite veins. C) Photomicrograph of K-708-R7 pyroxene hornblendite showing relationships between relict orthopyroxene (opx), serpentine (serp) and calcite. D) Photomicrograph of 6K-1431-R4 pyroxene hornblendite showing relationships between amphibole, orthopyroxene, and spinel. E) Photomicrograph of 6K-1431-R7 pyroxene hornblendite showing relationships between amphibole and spinel. F) Photomicrograph of 
6K-1432-R9 hornblende andesite porphyry showing relationships between hornblende phenocryst, plagioclase ( $\mathrm{pl}$ ) microphenocrysts, and fine-grained groundmass/matrix. This sample yields ${ }^{40} \mathrm{Ar} /{ }^{39} \mathrm{Ar}$ age of $47.60 \pm 0.15 \mathrm{Ma}$. G) Photomicrograph of $6 \mathrm{~K}-1432-\mathrm{R} 14$ altered basalt showing relations between amphibole and plagioclase microlites and zeolite alteration. H) 6K-1432-R15 altered basaltic andesite with altered plagioclase phenocryst. I) 6K-1432-R16 altered basalt/diabase showing relationships between plagioclase, amphibole, and magnetite. J) 6K-1432-R17 altered diabase showing relationships between amphibole and plagioclase. Scale bars for all but B) are 200 microns.

Fig. 5: Mineral compositions of amphibole, spinel, plagioclase and pyroxene. A) Amphibole SiMg\# plot showing the chemical variation for the studied rocks. Amphiboles of altered peridotite K-708-R7 have the highest Mg\#. Amphiboles in 6K-1431 samples are similar (mostly tschermakite) and have high Mg\# and low Si content. 6K-1431 amphiboles have lower Mg\# and higher Si content. Magnesio-hornblende in andesite 6K-1432-R9 is compositionally distinct from amphiboles in other 6K1432 samples B) plot of olivine and spinel compositions in $6 \mathrm{~K}-1431$ samples. These compositions plot well to the right of the olivine-spinel mantle array (OSMA; Arai, 1994). These compositions are expected for cumulates formed by fractional crystallization of mafic magmas. Data for peridotites studied by Ohara and Ishii (1998) are also shown for comparison. C) Plagioclase compositions for 6K-1432 samples. Plagioclase composition is mainly An50-90 range, although albite commonly forms along the rim and fractures of plagioclase phenocrysts in altered basalts and basaltic andesite R14, R15 and R17. D) Pyroxene quadrilateral showing compositions of orthopyroxene and clinopyroxene in. K-708-R07 altered peridotite contains only opx, which has the highest Mg\#. Only pyroxene hornblendites 6K-1431 contain co-existing cpx and opx. Only hornblende andesite 6K-1432-R9 contains cpx, which trends towards augite.

Fig. $6:{ }^{40} \mathrm{Ar} /{ }^{39} \mathrm{Ar}$ stepwise heating age spectra, $\mathrm{K} / \mathrm{Ca}$ ratios and inverse isochrons for 3 samples: A, B: 6K-1431-R7 olivine-2 pyroxene hornblendite; C, D: 6K-1432-R14 basalt; E, F: 6K1432-R14 hornblende andesite. All ages determined on amphibole separates.

Fig. 7: Rare Earth Element patterns (left) and primitive mantle-normalized trace element patterns for samples studied here. Patterns for young basaltic glasses (Stern et al., 2014) and 46.1 \pm 0.7 Ma diorite and tonalite (Reagan et al., 2018) are also shown. In B) Note remarkable enrichment of K-708-R7 altered peridotite in $\mathrm{Ba}, \mathrm{U}$, and Sr. Comparing A) and E), note similar LREE depletion of 47.2 $\pm 0.4 \mathrm{Ma}$ of ol 2-pyx hornblendites and hornblende bearing basalts, suggesting these are comagmatic. Note also that both hornblendites and related basalts are more depleted than young basaltic glasses.

Fig. 8: A) Zr/4-Nb*2-Y ternary tectonic discrimination diagram, after Meschede (1986). Most of the study samples plot in the arc/MORB fields except those that have undergone alteration. B) Plot of $\mathrm{Ta} / \mathrm{Yb}$ versus $\mathrm{Th} / \mathrm{Yb}$ after Pearce (2008). The study samples plot within the mantle array and just above the mantle array, consistent with derivation from subduction modified mantle. Also shown are fields for samples from the Southeast Mariana Forearc Rift from Ribiero et al. (2013), young volcanic glasses from Stern et al. (2014) and diorite and tonalite samples from Reagan et al (2018). 
Fig. 9: Profile along $143^{\circ} \mathrm{N}$, generated using GeoMapApp. A) shows overall bathymetry and position of transect shown in B). Depths of samples recovered from sites shown on Fig. 3 are projected onto profile in B). B shows depth of samples recovered from this study (K707, K-708, 6K-1431, 6K-1432) and also 6K-1363, reported by Stern et al. (2014).

Fig. 10: Compilation of ${ }^{40} \mathrm{Ar} /{ }^{39} \mathrm{Ar}, \mathrm{K}-\mathrm{Ar}$, and $\mathrm{U}-\mathrm{Pb}$ zircon dating results for igneous rocks from the IBM forearc, Kyushu-Palau Ridge (KPR), Amami-Sankaku Basin (ASB), and West Philippine Basin, modified after Ishizuka et al. (2018) to show results from the Challenger Deep Forearc Segment (this study).

Fig. 11: Plots of electron microprobe data of $\mathrm{A})$ amphibole $\left(\mathrm{Na}_{2} \mathrm{O}\right.$ versus $\left.\mathrm{SiO} 2\right)$, and $\left.\mathrm{B}\right)$ plagioclase $\left(\mathrm{Na}_{2} \mathrm{O}\right.$ versus $\left.\mathrm{FeO}\right)$ for rocks from the Challenger deep. Data are in Supplementary tables $1 \mathrm{~d}$ and 1e, respectively. Also shown in (A) are data for experimental amphibole-glass pairs from Molina et a. (2015) and for amphibole from the Jurassic Bonanza arc, Canada (Larocque and Canil (2009) for comparison. 


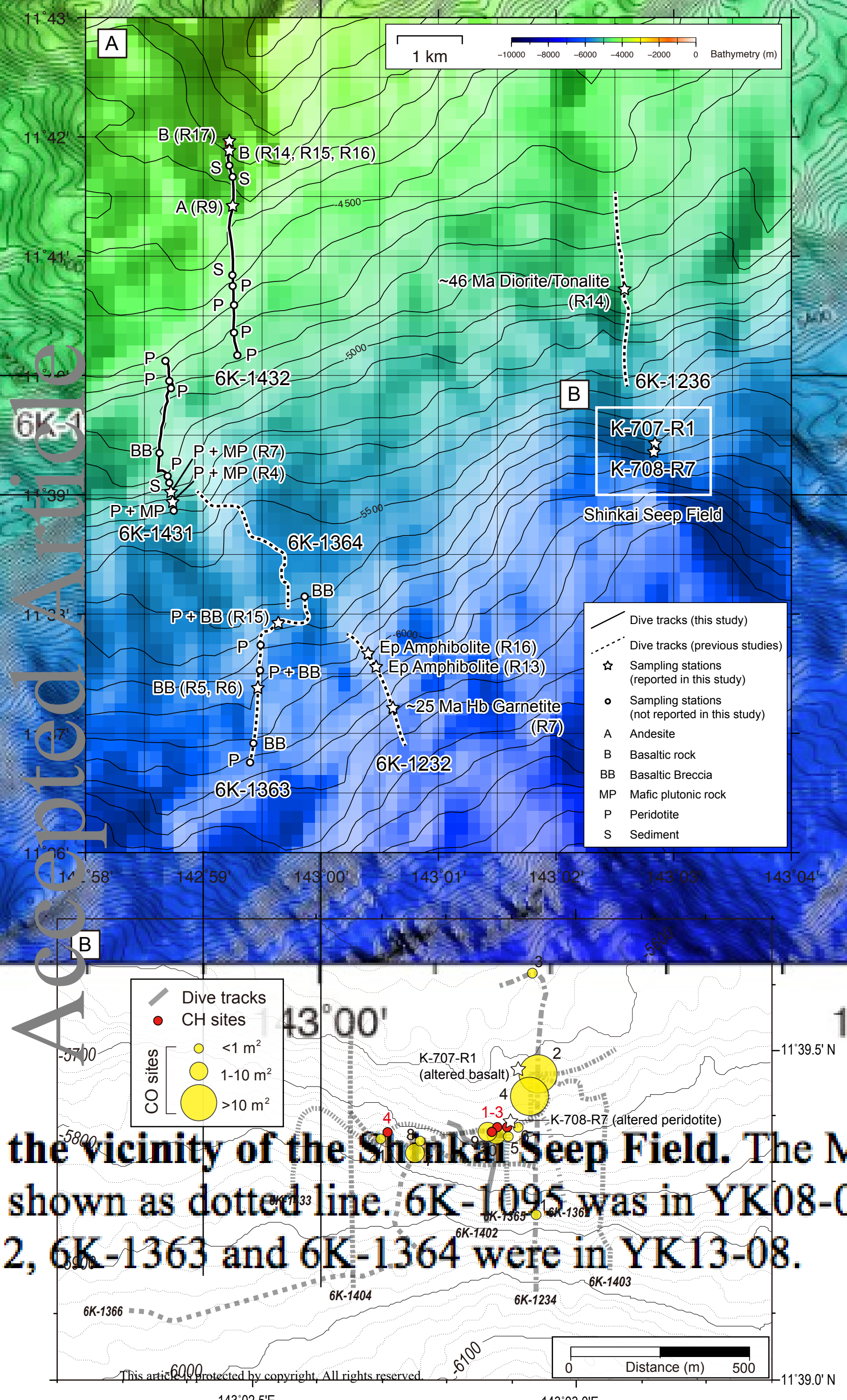



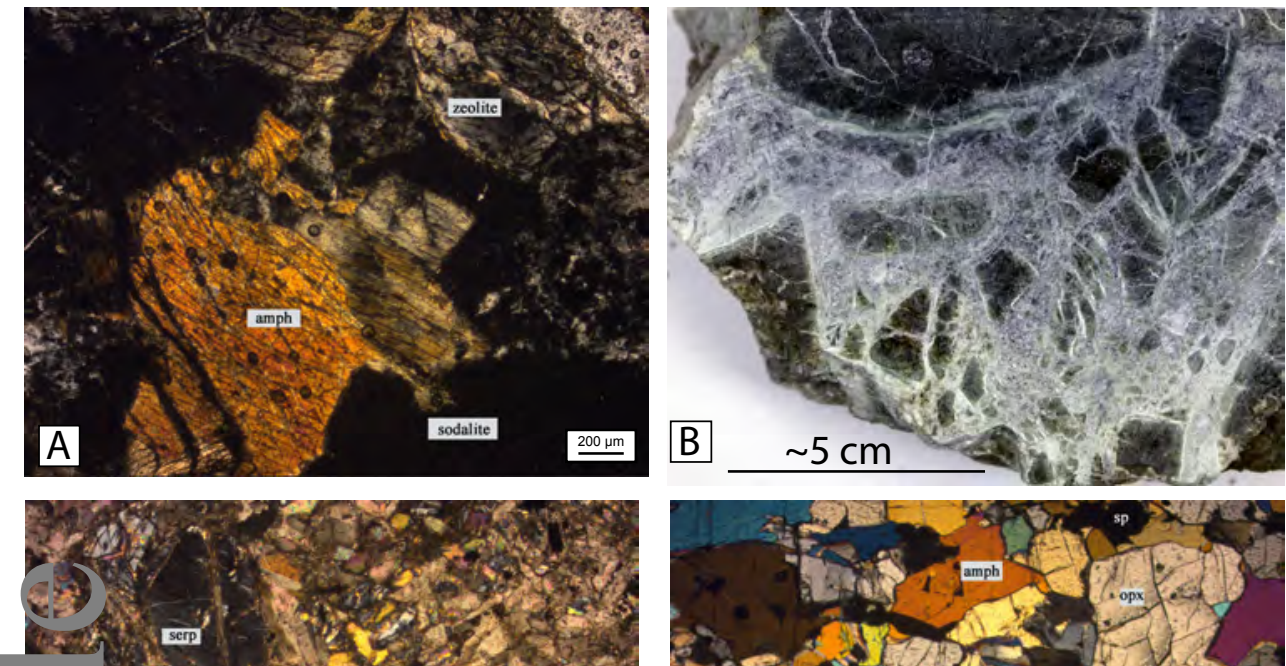

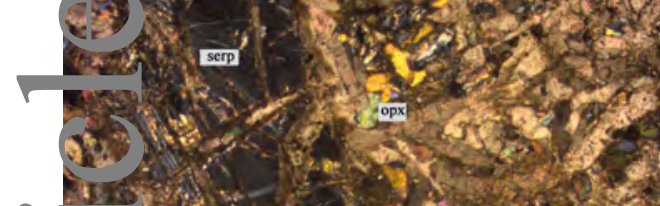

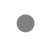

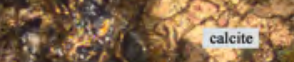

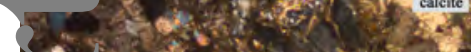

1.

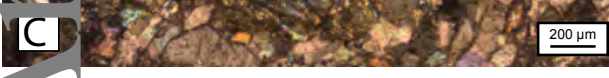

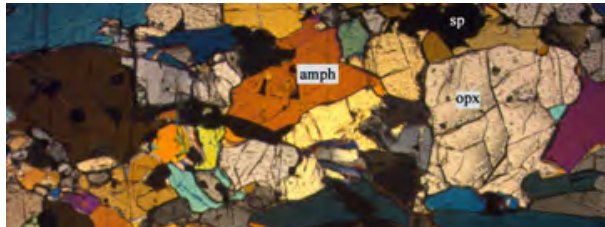

(1)

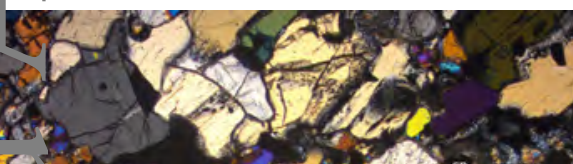

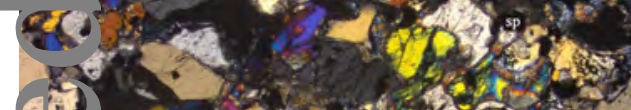

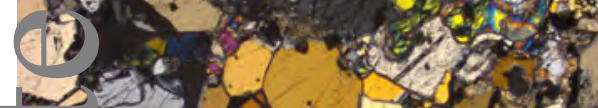

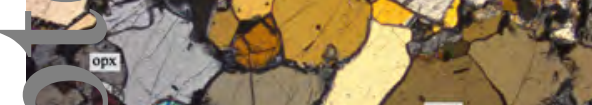

(

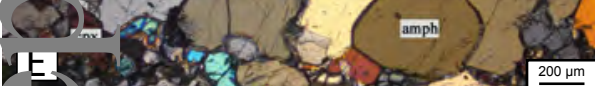

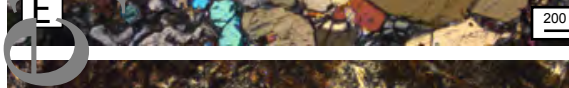

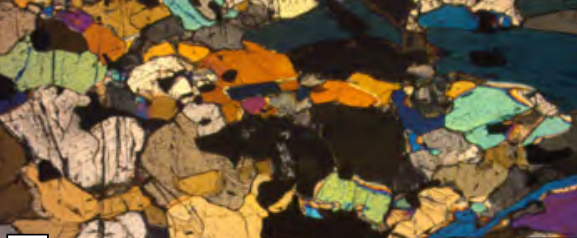

D 1 - . . - a n

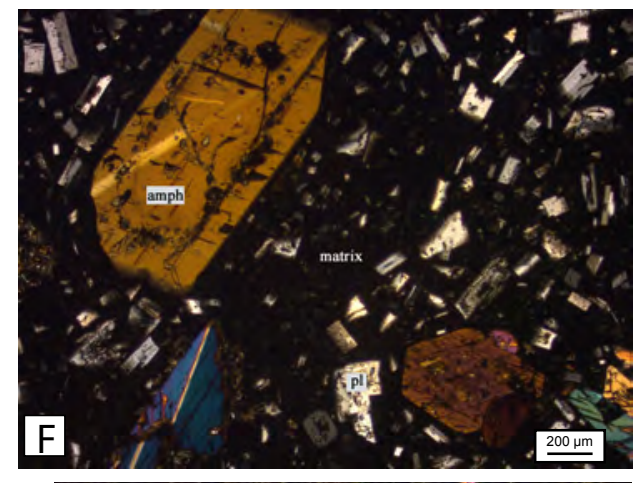

$$
\text { tet }
$$

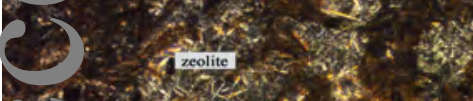

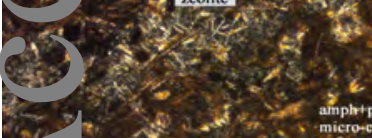

F.

G

$200 \mathrm{\mu m}$
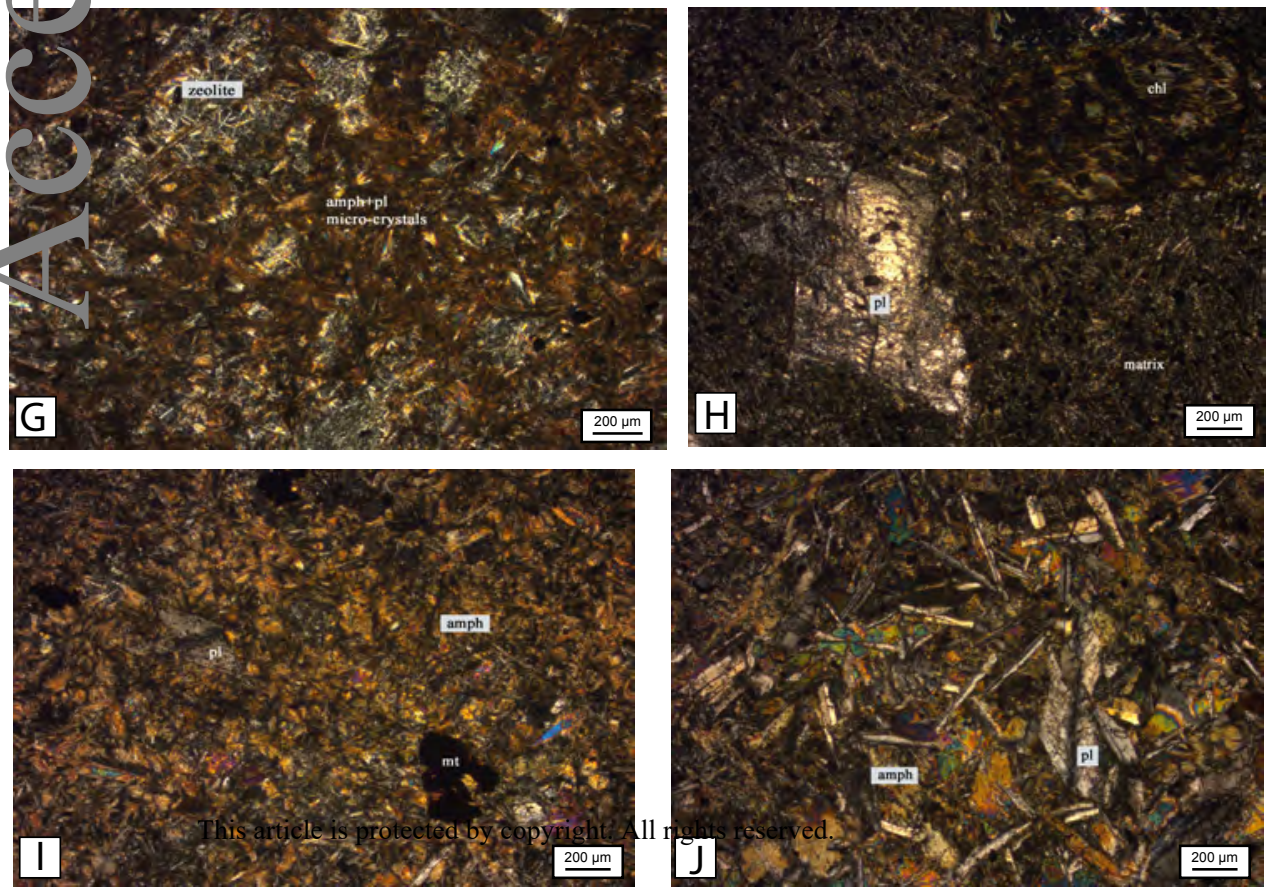

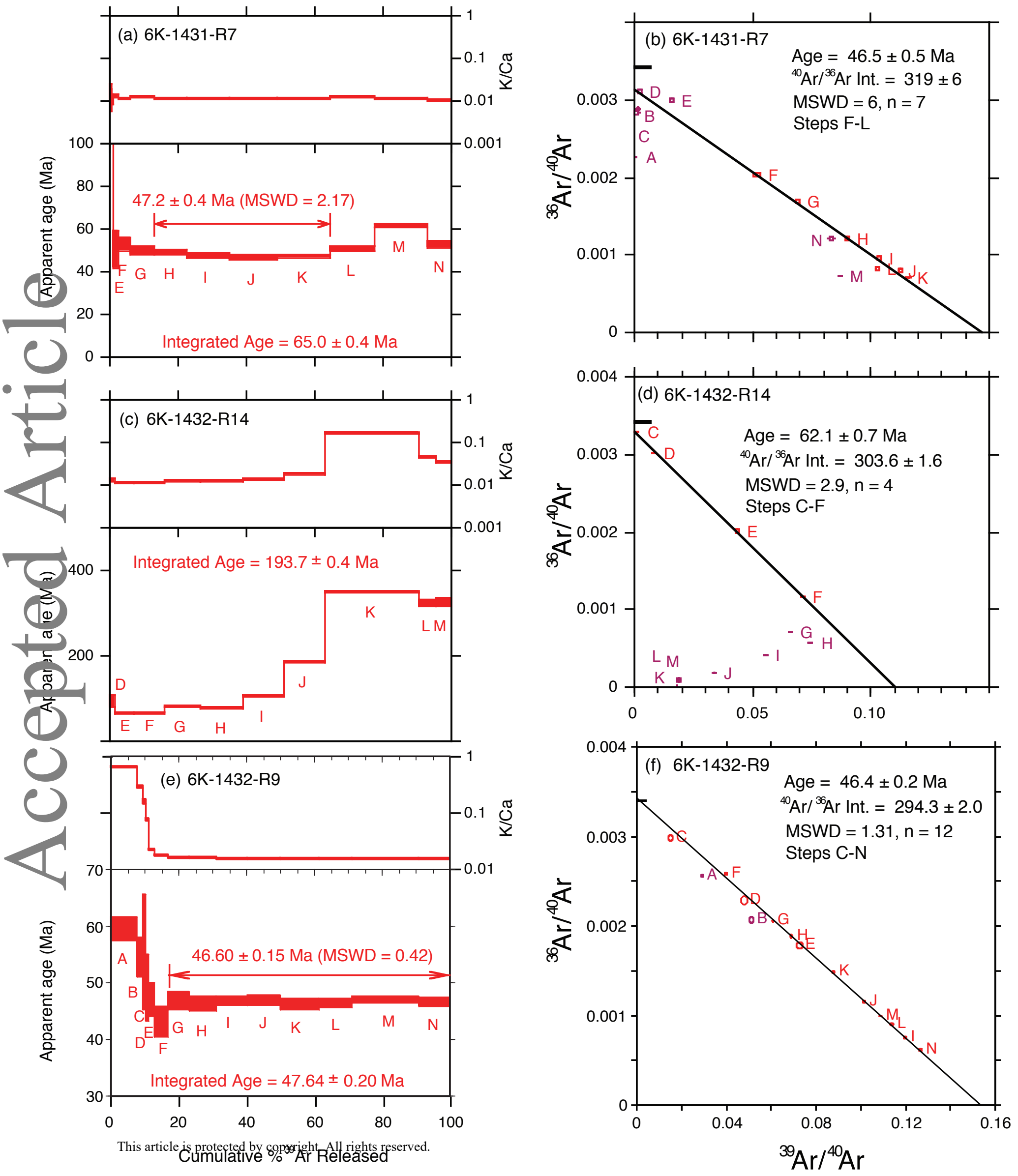

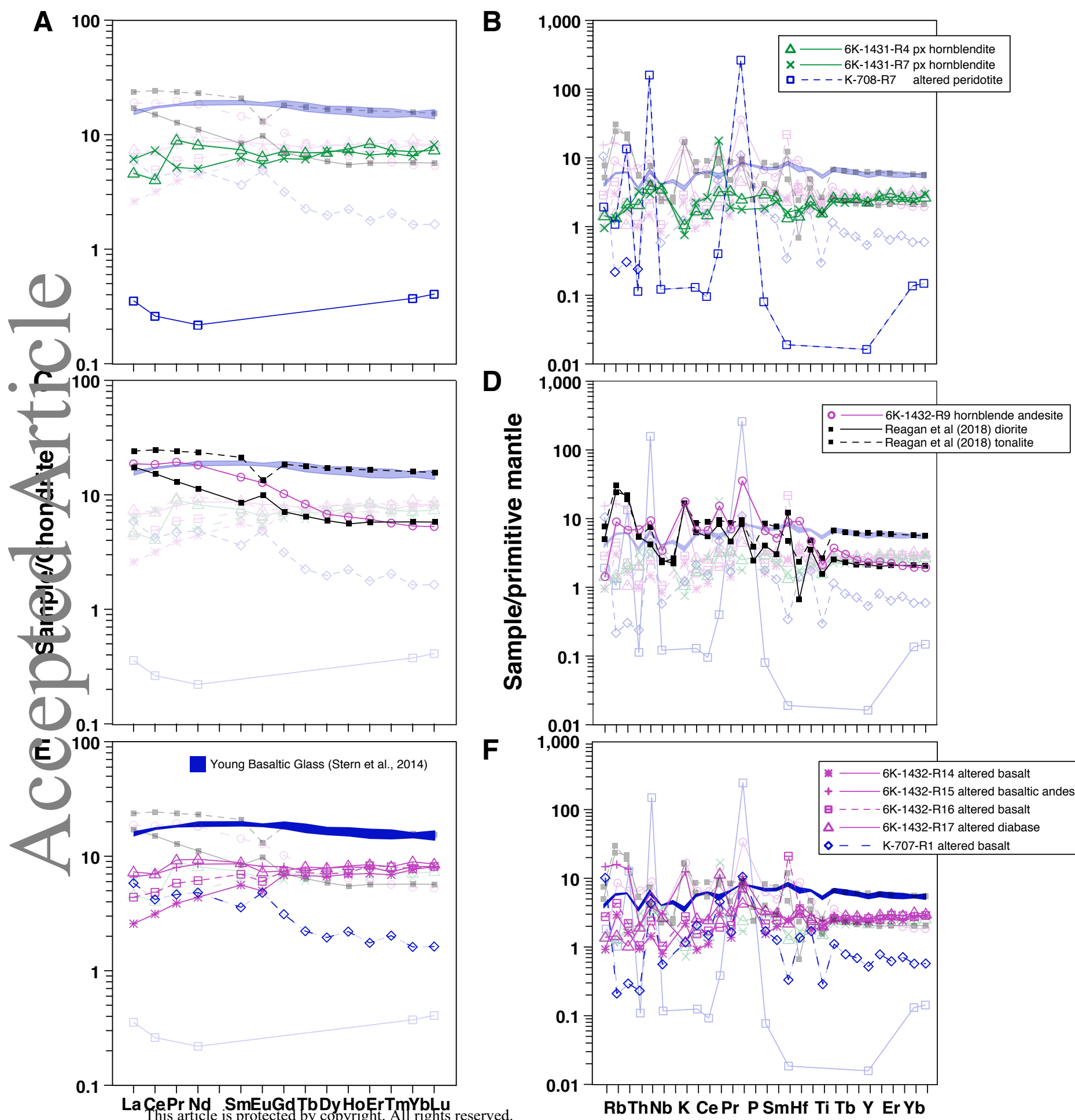

$F$

है
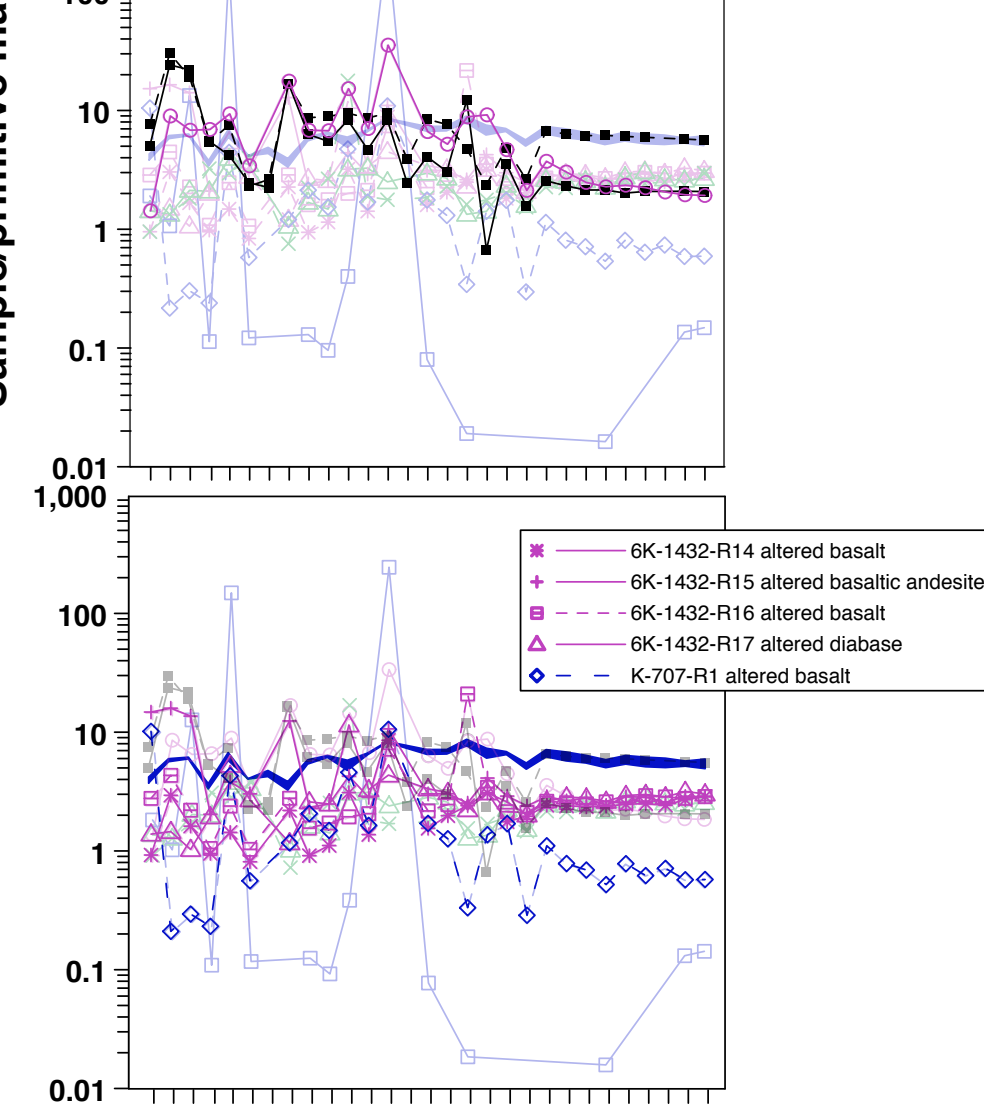

RbThNb K Ce Pr P SmHf Ti Tb Y Er Yb

CsBa U Ta La Pb Sr NdZr EuGdDyHoTmLu 

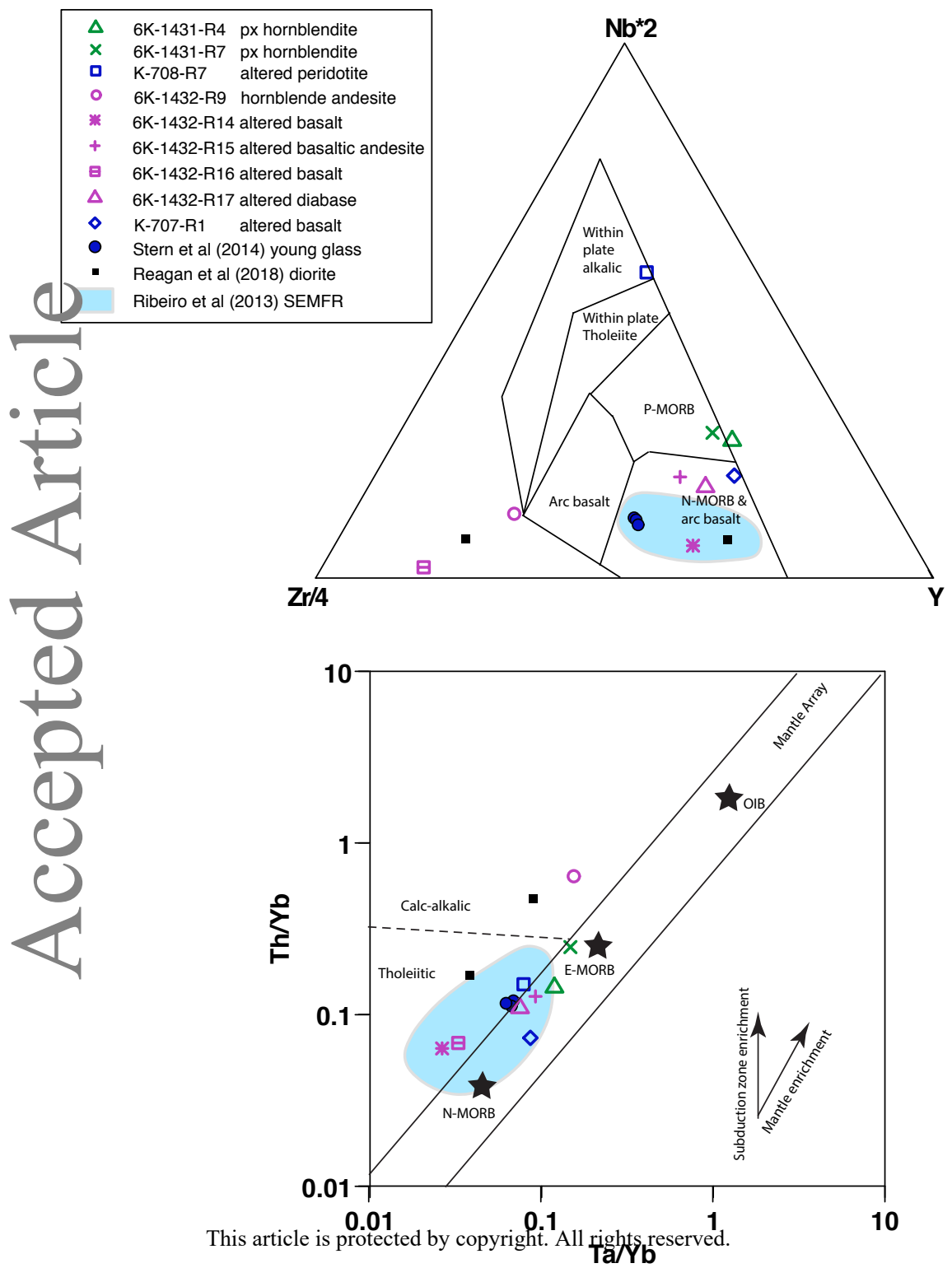


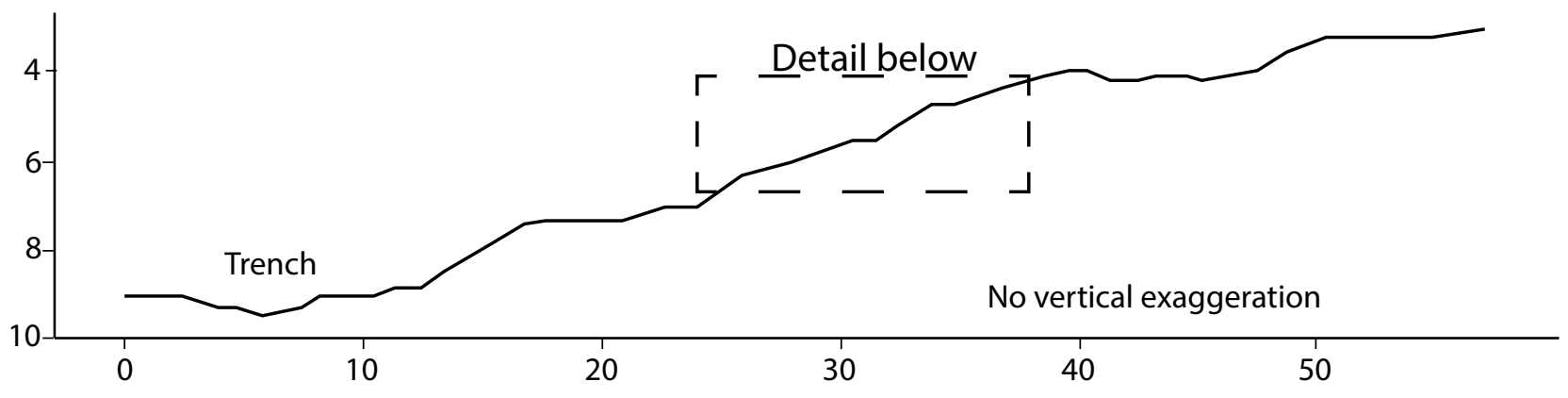
4- $\quad \mathrm{BB}=$ Young basaltic breccia
$\mathrm{P}=$ Peridotite
$\mathrm{AP}=$ Altered peridotite
$A B=$ Altered basalt
$M P=$ Mafic plutonic
$A=$ Andesite
$\mathrm{B}=$ Basalt, basaltic andesite, diabase
(1) $=\sim 25 \mathrm{Ma} \mathrm{Hb}$ Garnetite
(2) = Shinkai Seep Field
(3) $=\sim 46$ Ma Diorite/Tonalite

5

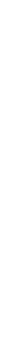

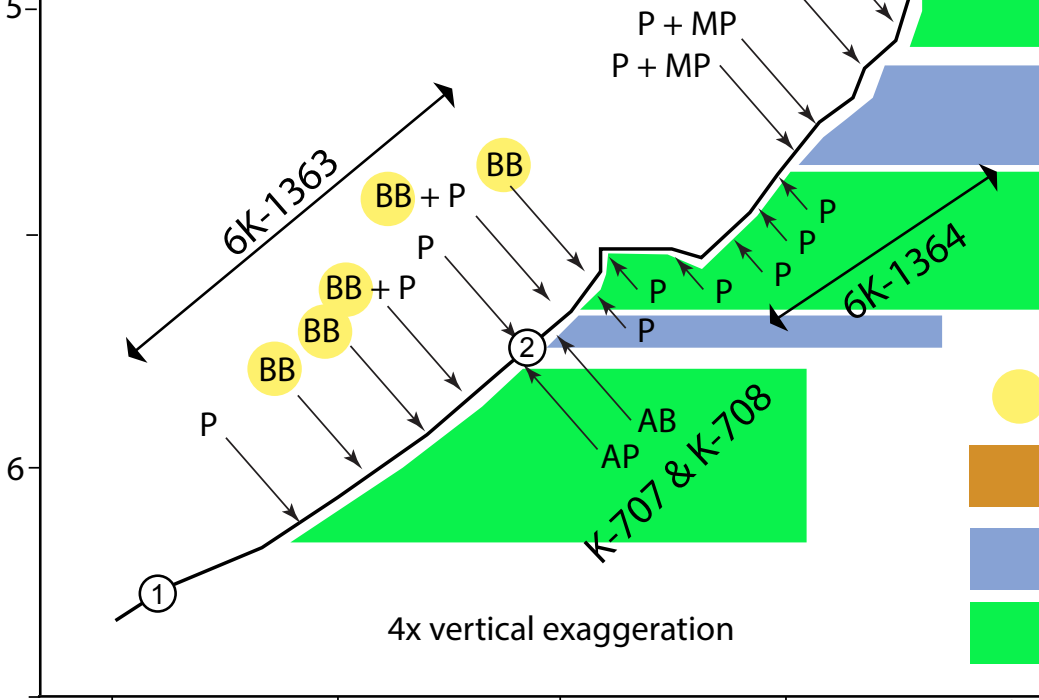

This article is proteced by copyright. All4ights reserved.

Young basaltic breccia

\section{Crust}

Mantle with mafic igneous

Mantle 


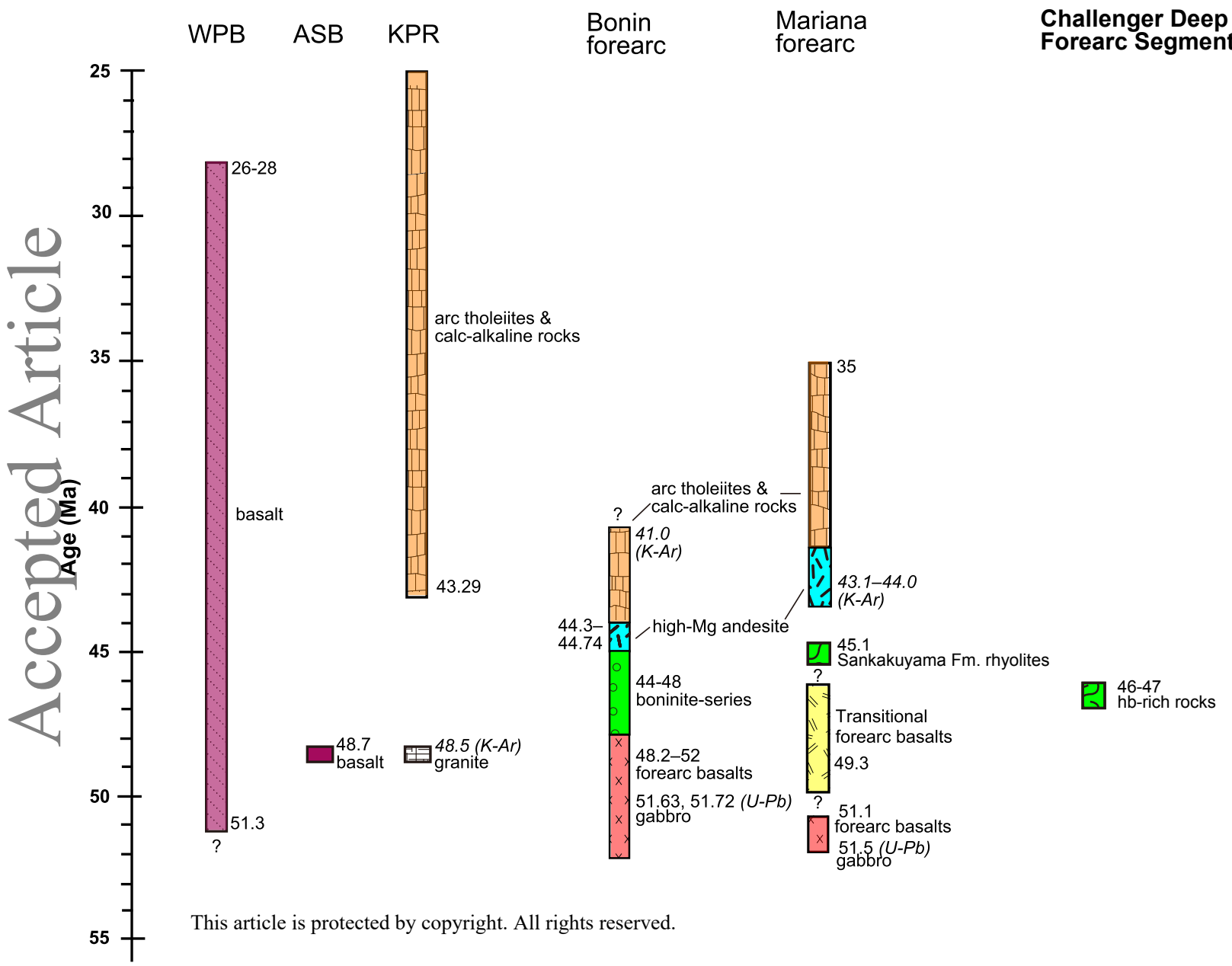



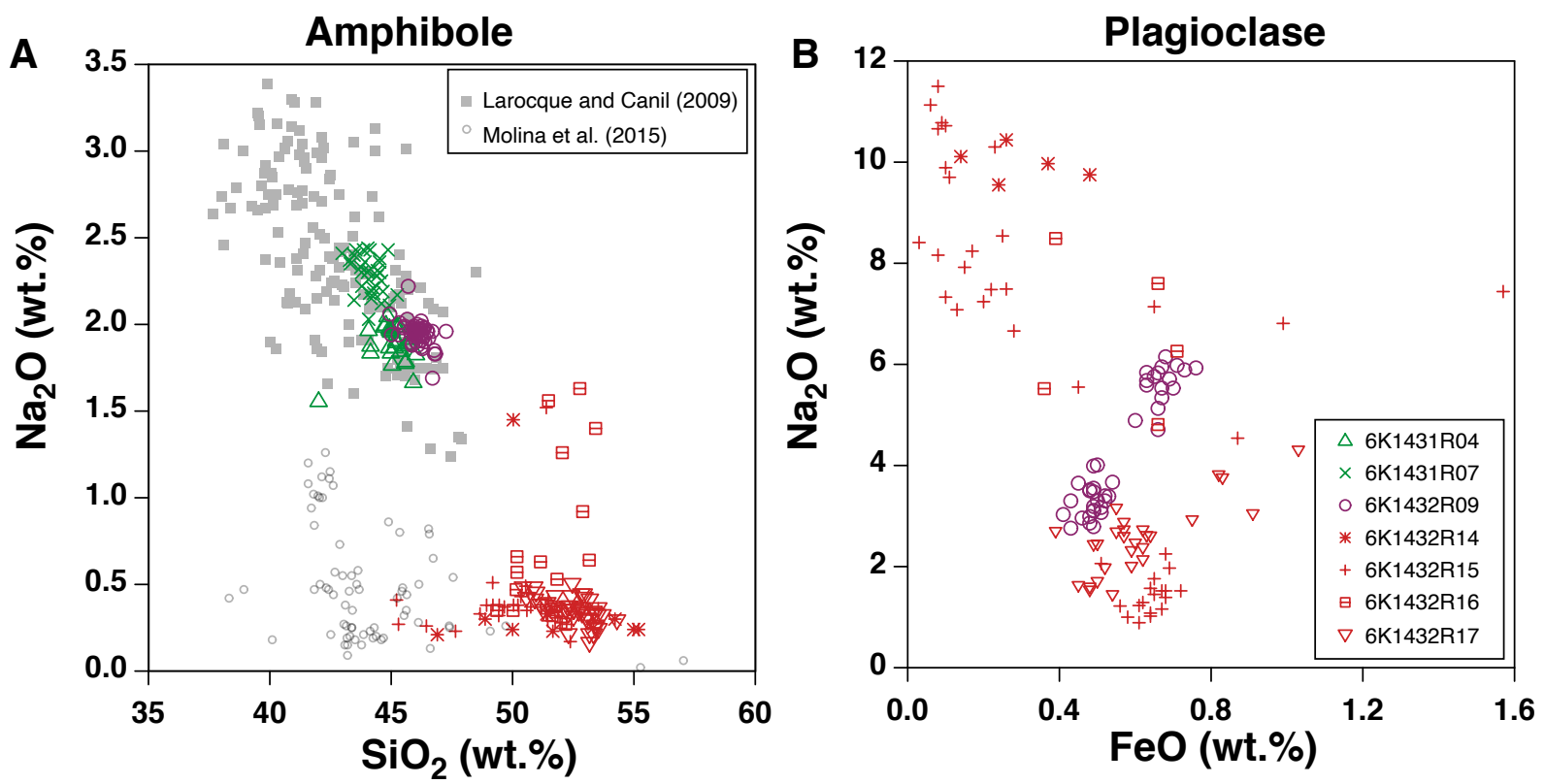